\title{
SYMPOSIUM ON TOXINS
}

\author{
Summary papers presented at the 17 th Symposium on Toxins held \\ at Kowakien, Hakone, Kanagawa-ken, on July 14 and 15, 1970. \\ Director: Dr. Tadayoshi Kasuga, the Kitasato Institute, Minato-ku, Tokyo
}

\section{CONTENTS}

Biochemical and immunochemical studies on cobrotoxin : C. C. Yang ..................... 26 Purification and some properties of toxin A from the venom of the Indian cobra

(Naja naja): KENJI NAKAI AND KYOZO HAYASHI ........................................ 27 Antigenicities of erabutoxins, neurotoxins from Laticauda semifaciata: NOBUO

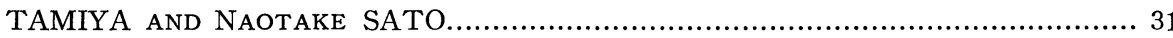

Studies on snake venom phospholipase A: Isolation, characteization and partial amino acid sequence: YUJI SAMEJIMA, SADAAKI IWANAGA, TOMOJI SUZUKI AND SAJU KAWAUCHI....................................................................... 31

Action of Trimeresurus flavoviridis venom on the microcirculatory system of rat; dynamic aspects as revealed by cinephotomicrographic recording: AKIRA OHSAKA, MAKOTO OHASHI, MASAHARU TSUCHIYA, YUKIYOSHI KAMISAKA AND YASUO FUZISHIRO

The mode of binding of sugars to ricin protein: SHIGERU NANNO, MASATSUNE ISHIGURO, GENKI FUNATSU AND MASARU FUNATSU.................................. 39

Site of action of cord factor in mitochondria : MASAHIKO KATO ........................ 42

The role of cord factor in pathogenesis of tuberculosis: MASAHIKO KATO ............ 47

Phage genetic analysis of the mechanism of synthesis of diphtherial toxin in nontoxinogenic Corynebacterium diphtheriae directed by nonlysogenizing phage: MORIHIRO MATSUDA, CHIE KANEI AND MASAHIKo YONEDA....................................... 51

Phage-conversion of toxigenicity in Clostridium botulinum types C and D : KATSUHIRO

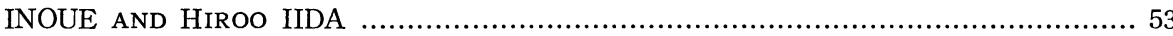

A toxic protein from insect pathogen Bacillus thuringiensis: SATORU AKUNE, TADAO WATANABE, JUN-ICHIRO MUKAI, RYOKI TSUTSUI AND KAZUNORI ABE ......... 57

Mechanism of hypersensitivity to histamine of rats treated with Bordetella pertussis vaccine: TokURo FUKUDA, NAmiYo HATA AND Setsuko AKIYAMA ............. 60

Biological activities of the protein moiety of Pseudomonas aeruginosa endotoxin: ChiYojI ABE, YUzURU HOMMA AND G. M. FUKUI ..................................... 64

Mechanism of the adjuvant effect of Salmonella lipopolysaccharide on antibody response at cellular level: MASAYASU NAKANO, TADAKATSU SHIMAMURA AND KAZUHISA SAITO

Hemorrhagic necrosis in mouse bone marrow induced by endotoxin and its relation to the hyperferremic reaction: MICHIMASA HIRATA, MASAO YOSHIDA AND

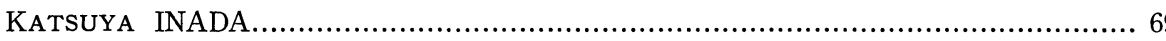

Studies on antitumor activity of bacterial lipopolysaccharide: IWAO UMEZAWA

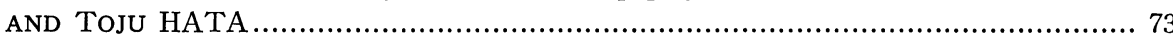

Characteristics of CIR (cell injuring reaction) active substance in culture fluid of Bacillus cereus, "MS-1063 strain": JUNJI TANAKA, RYUSAKU SHIMIZU AND MOTOICHI HATANO 


\title{
BIOCHEMICAL AND IMMUNOCHEMICAL STUDIES ON COBROTOXIN
}

\author{
C. C. YANG \\ Department of Biochemistry, Kaohsiung Medical College, Kaohsiung, \\ Taiwan, Republic of China
}

A toxic protein devoid of enzyme activities has been highly purified from Formosan cobra venom. The crystalline toxin, cobrotoxin, was found to be homogeneous and to be the main toxic protein in the venom. It consists of a single peptide chain cross-linked intramolecularly by 4 disulfide bonds with amino terminal leucine and carboxy terminal asparagine. The minimal molecular weight calculated from amino acid composition (62 residues) is 6,949. Since the complete sequence of amino acid in cobrotoxin has been determined and the positions of disulfide bonds clarified, two-dimensional schematic diagram for the structure of cobrotoxin was proposed.

On reduction with $\beta$-mercaptoethanol, cobrotoxin displays $8 \mathrm{SH}$ groups with a concurrent loss in toxicity. The reduced toxin yields on reoxidation a biologically active product with complete restoration of toxicity and antigenicity, specific rotation close to the native value and an infrared spectrum identical with that of cobrotoxin. The results indicate that the integrity of the disulfide bonds in cobrotoxin is essential for lethality.

ORD of cobrotoxin is quite different from those of the usual proteins in having a right-handed $\alpha$-helical structure and CD spectrum suggests that cobrotoxin molecule contains $\beta$-structure. On reductive cleavage of the disulfide bonds, cobrotoxin becomes a random conformation and the ORD and CD curves changed greatly. However, the reoxidized toxin gave essentially the same ORD and CD curves as cobrotoxin which suggests that correct reformation of helical structure occurred by air oxidation of the reduced protein.

Antisera have been prepared by injecting increasing doses of cobrotoxin with Freund's adjuvant into rabbits. Immunoglobulin $G$ isolated was allowed to react with cobrotoxin at equivalence. The antigen-antibody precipitates were dissolved in $0.53 \mathrm{M}$ formic acid and the antibody was separated from antigen through a column of Sephadex G-100. The purified antibody was proved to be free from antigen and $100 \%$ precipitable with cobrotoxin, and the neutralizing capacity increased 17.5-fold over that of the antisera.

The purified antibody was digested into univalent fragments with mercuripapain. The fragments do not form insoluble aggregates with antigen but from soluble antigen-antibody complex. The univalent fragments together with the purified antibody may provide valuable tools for an immunochemical approach to the elucidation of the toxic nature of snake venom. 


\title{
PURIFICATION AND SOME PROPERTIES OF TOXIN A FROM THE VENOM OF THE INDIAN COBRA (Naja naja)
}

\author{
KenjI NAKAI, Chieko NAKAI AND Kyozo HAYASHI \\ Department of Biological Chemistry, Faculty of Pharmaceutical Sciences \\ Kyoto University, Sakyo-ku, Kyoto, Japan
}

We reported previously on the purification, chemical structure and modifications of neurotoxins isolated from Formosan cobra (Naja naja atra) venom (Yang et al., 1967; Yang et al., 1968; Yang et al., 1969a; Hayashi et al., 1969; Chang and Hayashi, 1969). These studies have now prompted an investigation of other neurotoxins from different snake venoms in order to ascertain and compare possible structure-activity, genetic and evolutionary relationships. In this paper we describe the purification, end group analysis, and some properties of the major toxic principle from the venom of the Indian cobra (Naja naja).

Purification: The toxic proteins from the venom of the Indian cobra were purified by column chromatography on Sephadex G-75, G-50 and carboxymethylcellulose. The crude venom was gel-filtered with $1 \%$ acetic acid as solvent on a colum of Sephadex G-75 and separated into five fractions. Fraction G-IV contained most of the toxicity, and the recovery of protein from the crude venom was about $80 \%$ by weight. This fraction was further purified on Sephadex G-50. In this method, the fraction was separated into four fractions. The toxicity was concentrated in fraction G-IV-IV, which was obtained in a yield of $70 \%$ from fraction G-IV. Fraction G-IV-IV was further purified on a column of carboxymethyl-cellulose. Initially we eluted with $150 \mathrm{ml}$ of starting buffer and then with a 2-liter linear gradient $[0.005(\mathrm{pH} 5.8)$ to $0.5 \mathrm{M}(\mathrm{pH} 6.5)]$ sodium acetate buffer. The chromatography pattern was well reproducible. The most toxic fraction G-IV-IV-CM-VII was designated as "toxin A". This toxin shows a single band on polyacrylamide gel electrophoresis and was obtained in a yield of $17 \%$ from fraction G-IV-IV and $10 \%$ from the crude venom. Toxicity was also present in fractions G-IV-IV-CM-II to XI. Only the toxicity of fraction GIV-IV-X matched that of toxin A and was about 12-fold compared with the crude venom. Toxicities of other fractions were low by comparison with toxin A, which had an $\mathrm{LD}_{50}$ of $0.15 \mu \mathrm{g} / \mathrm{g}$ in mice.

Amino Acid Analysis: The amino acid analysis of toxin A is shown in Table 1. Toxin A contains 8 cystine residues but no methionine. In contrast to cobratoxin, toxin A contains alanine (2), pheneylalanine (3), and much more proline (6 instead of 2). Likewise all related neurotoxins from other snakes (Karlssone et al., 1966 ; Botes and Strydom, 1969; Yang et al., 1969 b), sea snake (Tamiya and Arai, 1966), and scorpion (Rochat et al., 1967) lack methionine. The amino acid composition in Table 1 was calculated on the basis of one residue of leucine or glutamic acid. The molecular weight calculated from the amino acid analysis agrees well with that determined by the method of equilibrium centrifugation measurements, 
Table 1. Amino Acid Composition of Neurotoxins from Snake Venom

\begin{tabular}{lccccc}
\hline $\begin{array}{c}\text { Amino } \\
\text { Acid }\end{array}$ & $\begin{array}{c}\text { Naja } \\
\text { naja } \\
\text { (Toxin A) }\end{array}$ & F-1 & $\begin{array}{c}\text { Naja } \\
\text { naja atra }\end{array}$ & $\begin{array}{c}\text { Naja } \\
\text { Figricolis } \\
\text { (Toxin } \boldsymbol{\alpha} \text { ) }\end{array}$ & $\begin{array}{c}\text { Naja } \\
\text { haje haje } \\
\text { (Toxin } \boldsymbol{\alpha})\end{array}$ \\
\hline Aspartic acid & 8 & 8 & 8 & 7 & 7 \\
Threonine & 7 & 8 & 8 & 8 & 7 \\
Serine & 4 & 4 & 4 & 2 & 4 \\
Glutamic acid & 1 & 7 & 7 & 6 & 7 \\
Proline & 6 & 2 & 2 & 5 & 4 \\
Glycine & 4 & 7 & 7 & 5 & 5 \\
Alanine & 2 & 0 & 0 & 0 & 0 \\
Half-cystine & 8 & 8 & 8 & 8 & 8 \\
Valine & 3 & 1 & 1 & 2 & 1 \\
Methionine & 0 & 0 & 0 & 0 & 0 \\
Isoleucine & 3 & 2 & 2 & 3 & 3 \\
Leucine & 1 & 1 & 1 & 2 & 1 \\
Tyrosine & 1 & 2 & 2 & 1 & 1 \\
Phenylalanine & 3 & 0 & 0 & 0 & 0 \\
Lysine & 3 & 3 & 3 & 6 & 6 \\
Histidine & 1 & 2 & 2 & 2 & 2 \\
Arginine & 5 & 5 & 6 & 3 & 4 \\
Tryptophan & 1 & 1 & 1 & 1 & 1 \\
\hline Total & 61 & 61 & 62 & 61 & 61 \\
\hline
\end{tabular}

Determination of the N-terminal Group: For comparison of toxin A with other neurotoxins, the N-terminal residue was firstly determined. Toxin A was reduced and carboxymethylated (Crestfield et al., 1963). The carboxymethyltoxin A was subjected to end group analysis by Edman degradation (Blombäck et al., 1966). Since the phenyl thiohydantoin amino acid so obtained would not differentiate between isoleucine and leucine, the residual protein was hydrolyzed with $6 \mathrm{~N} \mathrm{HCl}$ for $24 \mathrm{hr}$ and analyzed. The analysis clearly showed isoleucine to be the $\mathrm{N}$-terminal of toxin $\mathrm{A}$.

Subsequently, carboxymethyl-toxin A was taken through 16 cycles of successive Edman degradations to yield the following sequence: $\mathrm{NH}_{2} \cdot$ Ile-Arg-Asp-PheIle-Thr-Pro-Asp-Ile-Thr-Lys-Ala-Asp-Asp-Pro-Asn......

Determination of the C-terminal Group: For the analysis of the C-terminal group both the tritium method (Matsuo et al., 1966) and carboxypeptidase were used. No amino acids were released from carboxymethyl-toxin A by carboxypeptidase A or B, suggestive of proline at or near the $\mathrm{C}$-terminus (Harris and Knight, 1955). This assumption will require further studies. The C-terminus of toxin A was then labeled with tritium in the following way: To a solution of carboxymenthyl-toxin $\mathrm{A}$ in a mixture of $100 \mu \mathrm{l}$ of $\mathrm{T}_{2} \mathrm{O}(\mathrm{ca} .10 \mathrm{mc}$ ) and $0.2 \mathrm{ml}$ of pyridine was added $50 \mu \mathrm{l}$ of acetic anhydride and the mixture allowed to stand at room temperature for $5 \mathrm{hr}$. After the reaction labile tritium was removed by repeated evaporation and addition of water. Tritiated toxin A so obtained was hydrolyzed with $6.0 \mathrm{~N} \mathrm{HCl}$ and the hydrolysate purified by high voltage paper 
electrophoresis on Toyo No. 51 paper at pH 3.6. Tritium activity was strongest in the zone of the neutral amino acids and much weaker at the position of aspartic acid. The neutral amino acid zone was cut off and eluted with $10 \%$ acetic acid from the paper. After concentration, descending paper chromatography on Toyo No. 51 paper and development with a solvent system of water-saturated

\section{Toxin A \\ Toxin $\alpha$ (naja nigricolis) Erabutoxin b \\ Cobratoxin \\ Toxin $\alpha$ (naja haje haje) \\ F-I (naja naja atra)}

$\mathrm{NH}_{2} \cdot \mathrm{Ile}$-Arg-Asp-Phe-Ile-

$\mathrm{NH}_{2} \cdot$ Leu-Glu-Cys-His-Asn$\mathrm{NH}_{2}^{2} \cdot \mathrm{Arg}-\mathrm{Ile}-\mathrm{Cys}-\mathrm{Phe}-\mathrm{Asn}-$ $\mathrm{NH}_{2}^{2}$. Leu-Glu-Cys-His-Asn$\mathrm{NH}_{2}$-Leu-GIn-Cys-His-Asn$\mathrm{NH}_{2}$-Leu-GIu-Cys-His-Asn-

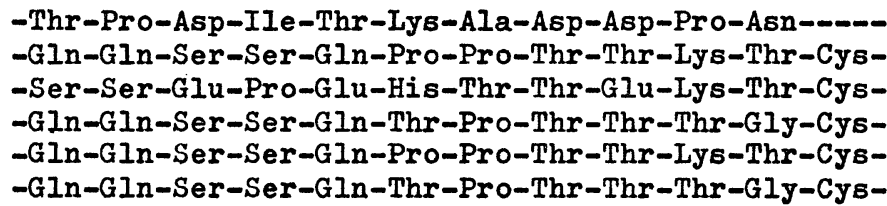

-Pro-Gly-Glu-Thr-Asn-Cys-Tyr-Lys-Lys-Val-Trp-Arg-Pro-Ser-GIy-Ser-GIn-Ser-Cys-Tyr-His-Lys-Gln-Trp-Ser-GIy-GIy-GIu-Thr-Asn-Cys-Tyr-Lys-Lys-Arg-Trp-Pro-Gly-Glu-Thr-Asn-Cys-Tyr-Lys-Lys-Arg-Trp-Arg-Ser-Gly-_-_-_-
-Asp-His-Arg-GIy-Thr-Ile-Ile-GIu-Arg-GIy-Cys-Gly-
-Ser-Asp-Phe-Arg-Gly-Thr-Ile-Ile-Glu-Arg-Gly-Cys-
-Arg-Asp-His-Arg-Gly-Tyr-Arg-Thr-Glu-Arg-Gly-Cys-
-Asp-His-Arg-GIy-Ser-Ile-Thr-GIu-Arg-Gly-Cys-GIy-

-Cys-Pro-Thr-Val-Lys-Pro-Gly-Ile-Lys-Leu-Asn-Cys-Gly-Cys-Pro-Thr-Val-Lys-Pro-Gly-Ile-Lys-Leu-Ser-Gly-Cys-Pro-Ser-Val-Lys-Asn-GIy-Ile-GIu-Ile-Asn-Cys-Pro-Ser-Val-Lys-Lys-Gly-Ile-Glu-Ile-Asn-Cys-

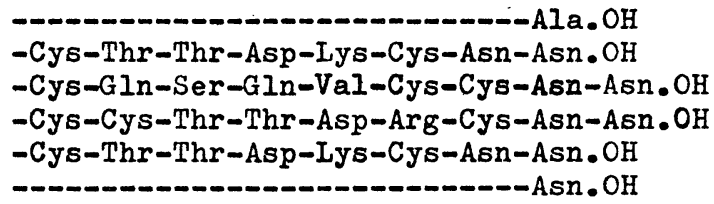

Fig. 1. Structures of Naja naja neurotoxin (Toxin A), Naja nigricollis neurotoxin (Toxin $\boldsymbol{\alpha}$ ), Laticauda semifasciata neurotoxin (Erabutoxin b), Naja naja atra neurotoxin (Cobratoxin), Naja haje haje (Toxin $\boldsymbol{\alpha}$ ), and Naja naja atra neurotoxin (F-1). Dotted lines indicate parts where the sequence has not been determined. 
phenol showed the radioactive $\mathrm{C}$-terminal amino acid to be alanine.

The neurotoxins from snakes of the family Elapidae are particularly potent. The venom of the Indian cobra furnished several toxic proteins, of which the major toxic principle was obtained as toxin $\mathrm{A}$ in a yield of $10 \%$ (weight) from the crude venom. Toxin A differed not only in the amino acid composition considerably from other neurotoxins (Table 1), but also in its pharmacological properties; toxin A was curare-like in contrast to the CNS effects of scorpion neurotoxin. The sequence of the first 16 amino acids and the $\mathrm{C}$-terminal residue have been determined.

As shown in Fig. 1, the amino acid sequence of toxin A differs from the neurotoxins isolated from the family of Elapidae, whose amino acid sequences have been determined (Karlsson et al., 1966; Botes and Strydom, 1969; Yang et al., $1969 \mathrm{~b}$; Sato and Tamiya, 1968). The complete amino acid sequence of toxin $\mathrm{A}$ and the active site of the venom are currently under investigation.

\section{REFERENCES}

Blomb̈̈̈K, B., Bblombäck, M., Edman, P. ANd Hessel, B. (1966): Human fibrinopeptides: Isolation, characterization and structure. Biochim. Biophys. Acta, 115, 371-396.

Botes, D. F. AND STRYdom, D. J. J. (1969): A neurotoxin, Toxin $\boldsymbol{\alpha}$, from Egiptian cobra (Naja haje haje) venom. I. Purification, properties, and complete amino acid sequence. J. Biol. Chem., 244, 4147-4157.

Chang, C. C. AND HAYAShi, K. (1969): Chemical modification of the tryptophan residue in cobratoxin. Biochem. Biophys. Res. Commun., 37, 841-846.

Crestfield, A. M., Moore, S. ANd Stein, W. H. (1963): The preparation and enzymatic hydrolysis of reduced and S-carboxymethylated proteins. J. Biol. Chem., 238, 622.

HARRIS, J. I. AND KNIGHT, C. A. (1955): Studies on the action of carboxypeptidase on tabacco mosaic virus. J. Biol. Chem., 214, 215-230.

HAYASHI, K., NAKaI, K., SASAKI, T. AND Suzuki, T. (1969): The N- and C-terminal amino acid sequences of cobratoxin from Formosan cobra venom. Biochem. Biophys. Res. Commun., 36, 482-486.

KARLSSON, E., EAKER, D. L. AND PORATH, J. (1966): Purification of a neurotoxin from the venom of Naja nigricollis. Biochim. Biophys. Acta, 127, 505-520.

Matsuo, H., Fujimoto, Y. And TAtsuno, T. (1966): A novel method for the determination of C-terminal amino acid in polypeptides by selective tritium labelling. Biochem. Biophys. Res. Commun., 22, 69-74.

Rochat, C., Rochat, H., Miranda, F. And Lissitzky, S. (1967): Purification and some properties of the neurotoxins of Androctonus australis Hector. Biochemistry, 6, 578-585.

TAMIYA, N. AND ARAI, H. (1966): Crystallization of erabutoxins a and b from Laticauda semifasciata venom. Biochem. J., 99, 624-630.

SAto, N. AND TAmiYa, N. (1968): The primary structure of erabutoxin. Abs. of the 19th Symposium on Protein Structure at Tokyo, 13-16,

Yang, C. C., Chang, C. C., Hamaguchi, K., Ikeda, K., Hayashi, K. and Suzuki, T. (1967): Optical rotatory dispersion of cobrotoxin. J. Biochem., 61, 272-274.

Yang, C. C., Chang, C. C., Hayashi, K., Suzuki, T., Ikeda, K. And Hamaguchi, K. (1968): Optical rotatory dispersion and circular dichroism of cobrotoxin. Biochim. Biophys. Acta, 168, 373-376.

Yang, C. C., Chang, C. C., Hamaguchi, K., Ikeda, K., Hayashi, K. and Suzuki, T. $(1969 \mathrm{a})$ : Amino acid composition and end group analysis of cobrotoxin. Toxicon, 7, $43-47$. 
YANG, C. C., YANG, H. J. AND HUANG, J. S. (1969 b): The amino acid sequence of cobrotoxin. Biochim. Biophys. Acta, 188, 65-77.

\title{
ANTIGENICITIES OF ERABUTOXINS, NEUROTOXINS FROM LATICAUDA SEMIFACIATA
}

\author{
Nobuo TAMIYA AND NAOTAKE SATO \\ Department of Chemistry, Faculty of Sciences, Tohoku University, Sendai, Japan
}

\section{STUDIES ON SNAKE VENOM PHOSPHOLIPASE A: ISOLATION, CHARACTERIZATION AND PARTIAL AMINO ACID SEQUENCE*}

\author{
Yuji SAMEJIMA, SADAAKI IWANAGA, TOMOJI SUZUKI \\ AND SAJU KAWAUCHI** \\ Division of Plasma Proteins, Institute for Protein Research, Osaka University, \\ Osaka and **Hoshi College of Pharmacy, Shinagawa-ku, Tokyo, Japan
}

Many biochemically important substances have been found in animal venoms with extremely higher concentration than in tissue extracts and body fluids. The content of phospholipase A (phosphatide acyl-hydrolase, EC 3. 1. 1. 4) is also relatively higher in several animal venoms from snake, been an scorpion. The venom of $A$. halys blomhoff, "Mamushi" in Japanese, was proved to contain two types of phospholipase A, A-I and A-II (Iwanaga and Kawauchi, 1959). These two enzymes were separated by chromatography on DEAE-cellulose and each protein was purified further on a column of P-cellulose and CM-cellulose for A-I, and Sephadex G-100 and DEAE-Sephadex A-25 for A-II. They were found to be homogeneous physicochemically by sedimentation analysis, ion exchange chromatography and disc electrophoresis with polyacrylamide gel. The enzyme A-I had a sedimentation constant of $1.80 \mathrm{~S}$ and an average molecular weight, as determined by two different methods, of $13,800( \pm 500)$. The protein was strongly basic as indicated by an isoelectric point of $\mathrm{pH}$ 10.0. The enzyme A-II, on the other hand, had a sedimentation constant of $1.90 \mathrm{~S}$, a diffusion constant of 13.35 $\times 10^{-7} \mathrm{~cm}^{2} \cdot \mathrm{sec}^{-1}$, and an average molecular weight, as determined by three different methods, of $13,700( \pm 500)$. The protein was relatively acidic as indicated with an isoelectric point of $\mathrm{pH}$ 4.0. Thus, the two enzymes significantly differ in their charge distribution of the protein molecules.

\footnotetext{
* Part of this work was presented at the 40th Annual Meeting of the Japanese Biochemical Society. Abst.: J. Jap. Biochem. Soc., 41, 445 (1969). The abbreviation used are; A: Agkistrodon, PCMB: p-Chloromercuribenzoic acid, PITC: Phenylisothiocyanate, CPase $\mathrm{A}$ and $\mathrm{B}$ : Carboxypeptidase A (EC 3.4.2.1) and B (EC 3.4.2.2), CNBr: Cyanogen bromide.
} 
Chemical analyses of the proteins of A-I and A-II revealed, repectively, $14.44 \%$ and $15.45 \%$ as total nitrogen and $2.98 \%$ and $3.18 \%$ as total sulfur. Thus, a relatively higher amount of sulfur was estimated with both proteins; however, no free sulfhydryl groups were titrated by PCMB. Hexoses, hexosamines and sialic acid quantitated in both proteins were insignificant (Kawauchi and Suzuki, 1968). On amino acid analyses, the two enzymes gave the same total residues of 126. A-I consisted of the following composition; $\mathrm{Asp}_{14}, \mathrm{Thr}_{6}$, $\mathrm{Ser}_{5}, \mathrm{Glu}_{6}, \mathrm{Pro}_{5}, \mathrm{Gly}_{10}, \mathrm{Ala}_{5}, \mathrm{Half}_{-\mathrm{Cys}_{14}}, \mathrm{Val}_{4}, \mathrm{Met}_{3}, \mathrm{Ile}_{7}, \mathrm{Leu}_{5}, \mathrm{Tyr}_{10}, \mathrm{Phe}_{5}, \mathrm{Lys}_{17}$, $\mathrm{His}_{2}, \mathrm{Arg}_{6}, \operatorname{Trp}_{2}$. While, A-II showed the composition; Asp $\mathrm{Ar}_{17}, \mathrm{Thr}_{5}, \mathrm{Ser}_{4}, \mathrm{Glu}_{13}$, $\mathrm{Pro}_{5}, \mathrm{Gly}_{13}, \mathrm{Ala}_{7}, \mathrm{Half}_{-\mathrm{Cys}_{14}}, \mathrm{Val}_{4}, \mathrm{Met}_{2}, \mathrm{Ile}_{7}, \mathrm{Leu}_{5}, \mathrm{Tyr}_{10}, \mathrm{Phe}_{5}, \mathrm{Lys}_{8}, \mathrm{His}_{1}, \mathrm{Arg}_{4}$, $\operatorname{Trp}_{2}$. As mentioned above, clear difference between the two enzymes was found in the number of glutamic acid and lysine residues. This seems to contribute to the difference between A-I and A-II in the isoelectric point. A common characteristic is that half-cystine contents of both phospholipases are extremely high, constituting more than $10 \%$ of the total amino acid residues. The high contents of tyrosine and lysine residues are also interesting.

To study the relation of the structure and function of the phospholipase A molecule, its amino acid sequence on the enzyme A-II was investigated.

On the $\mathrm{N}$-terminal analysis of the native protein by Edman degradation (Blombäck et al., 1966), no N-terminal amino acid reactive with PITC was found. The C-terminal end was also resistant to CPase A and B. However, qualitative analysis using the selective tritium labelling procedure for the $\mathrm{C}$-terminal amino acid (Matsuo et al., 1966) revealed a single spot, corresponding to cystine on paper chromatograms with two solvent systems.

First, selective cleavage of the whole protein with cyanogen bromide (Cahnmann et al., 1966) was attempted and two major peptide fragments, Br-I and Br-III, were obtained on a column of Sephadex G-50. The large fragment, Br-I, was composed of a total of 111-114 amino acid residues and in this fragment all the half-cystine residues of the starting material were recovered but no homoserine was detected. Edman degradation of $\mathrm{Br}$-I gave $\mathrm{N}$-terminal lysine and subsequent analysis revealed the sequence, Lys-Ile-Ala-Gly-Arg......

$\mathrm{Br}$-III was separated into two main peptides, $\mathrm{Br}$-III-A and $\mathrm{Br}$-III-C, using a column of Dowex 50-X2. Each peptide contained one mole of homoserine, indicating that the two methionine residues found in the whole protein are recovered in these fragments. N-terminal end of Br-III-A was not detectable, while that of $\mathrm{Br}$-III-C was serine. Sequence analyses of Br-III-A and Br-III-C using Edman degradation, CPase A digestion and alignment of the small peptides obtained after acid hydrolysis (Titani and Narita, 1964) supported the structure of *GluPhe-Glu-Thr-Leu-Ile-Met for the former and Ser-Leu-Met for the latter. The native protein had no N-terminal and the Br-I-fragment had no homoserine residue, so the $\mathrm{CNBr}$-fragments should be arranged with the sequence of $\mathrm{Br}$-III$\mathrm{A} \rightarrow \mathrm{Br}$-III-C $\rightarrow \mathrm{Br}-\mathrm{I}$.

CNBr-fragment, Br-I, was reduced and carboxymethylated (Crestfield et al., 1963) and then digested with TPCK-treated trypsin (Wang and Carpenter, 1965). The digest was fractionated in a Technicon peptide analyzer and some of the

* Evidence strongly suggests that this residue is pyroglutamic acid. 
tryptic peptides were further purified by gel-filtration, paper chromatography and electrophoresis. Six main peptides and three minor peptides were finally obtained and their amino acid sequences so far determined are shown in Table 1. In these peptides, T-1-2 must be located in the C-terminal part of the whole protein, as it contains $\mathrm{C}$-terminal carboxymethylcysteine like the whole enzyme. The fragment, T-8, consisting of 43 amino acid residues, is probably connected to Br-III-C through T-7-1, which was identified to be lysine, because the $\mathrm{N}$ terminal sequence (Ile-Ala-Gly-Arg-) of T-8 was identical with the sequence of 4 residues next to lysine found as the $\mathrm{N}$-terminus of undegraded $\mathrm{Br}$-I.

Table 1. Partial amino acid sequences of peptide fragments

\begin{tabular}{|c|c|}
\hline $\mathrm{Br}-\mathrm{I}$ & 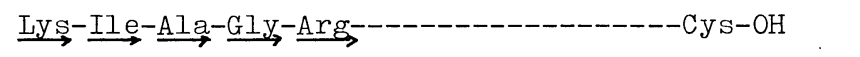 \\
\hline $\mathrm{Br}-\mathrm{I}-\mathrm{CMI}$ & $\stackrel{\mathrm{Ly} S}{\longrightarrow}-\mathrm{Il} \mathrm{\longrightarrow}-\mathrm{Ala}-\mathrm{GIy}-\mathrm{Arg}-$ \\
\hline $\mathrm{Br}-\mathrm{III}-\mathrm{A}$ & Glu-Phe-Glu-Thr-Leu-Ile-Met-OH \\
\hline $\mathrm{Br}-\mathrm{III}-\mathrm{C}$ & $\stackrel{\mathrm{Ser}}{\longrightarrow}-\mathrm{Leu}-\mathrm{Met}-\mathrm{OH}$ \\
\hline$T-1-2$ & $\stackrel{\mathrm{Asn}}{\longrightarrow}-\mathrm{Cys}-\stackrel{\mathrm{Gln}}{\longrightarrow}-\mathrm{Cys}-\stackrel{\mathrm{Glu}}{\longrightarrow}-(\mathrm{Pro}, \mathrm{Ser}, \mathrm{Glx})-\stackrel{\mathrm{Glu}}{\longrightarrow}-\mathrm{Cys}-\mathrm{OH}$ \\
\hline $\mathrm{T}-3$ & $\stackrel{\text { Asp }}{\longrightarrow} \stackrel{\text { Asn }}{\longrightarrow}-\mathrm{Il} e-\mathrm{Cys}-\mathrm{Thr} \longrightarrow \longrightarrow$ \\
\hline$T-4-S-2$ & $\stackrel{\mathrm{Val}}{\longrightarrow} \stackrel{\mathrm{Th} r}{\longrightarrow}-\stackrel{\mathrm{Asp}}{\longrightarrow}-\mathrm{Gly}-\left(\mathrm{Pro}, \mathrm{Asx}, \mathrm{Cys}_{2}\right)-\mathrm{Lys}-\mathrm{OH}$ \\
\hline $\mathrm{T}-6-2$ & $\stackrel{\mathrm{Cys}}{\longrightarrow}-\mathrm{Cys}-\mathrm{Phe}-\mathrm{Val}-\mathrm{Asp}-\mathrm{Hi} \underset{\longrightarrow}{\longrightarrow}-\left(\mathrm{Tyr}, \mathrm{Gly}, \mathrm{Cys}_{2}\right)-\mathrm{Lys}-\mathrm{OH}$ \\
\hline T-8 & 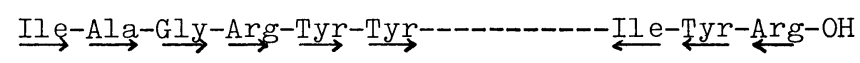 \\
\hline T-7-1 & Lys \\
\hline T-9 & 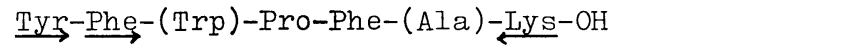 \\
\hline
\end{tabular}

From these data, the following tentative gross structure is drawn for phospholipase A-II.

*Glu-Phe-Glu-Thr-Leu-Ile-Met-Ser-Leu-Met-Lys-Ile-Ala-Gly-Arg-Tyr-Tyr ......

$\stackrel{\text { (T-4-S-2, T-6-2, T-9, T-3)-Asn-Cys-Gln-Cys-Glu-(Pro, Ser, Glx)-Glu-CysOH }}{\longrightarrow}$ T-1-2-

During the course of this study, Maroux et al. published a note on the primary structure of porcine pancreatic phospholipase A (Maroux et al., 1969). The homology of the sequences of the enzymes from pancreas and venom extracted from the submaximally gland of venomous snake is quite an interesting problem which we are now investigating.

\section{REFERENCES}

Blombäck, B., Blomb̈̈̈к, M., Edman, P. AND Hessel, B. (1966): Human Fibrinopeptides.

Isolation, Characterization and Structure. Biochim. Biophys. Acta, 115, 371.

CAhnmann, H. J., ARnon, R. AND SELA, M. (1966): Isolation and Characterization of 
Active Fragments obtained by Cleavage of Immunoglobin G with Cyanogen Bromide. J. Biol. Chem., 241, 3247.

Crestfield, A. M., Moore, S. ANd Stein, W. H. (1963): The Preparation and Enzymatic Hydrolysis of Reduced and S-Carboxymethylated Proteins. J. Biol. Chem., 238, 622.

Iwanaga, S. AND Kawauchi, S. (1959): Studies on Snake Venoms. V. Column Chromatography of Lecithinase A in Japanese Mamushi Venom (A. halys blomhoffii Boie). J. Pharm. Soc. Japan (in Japanese), 79, 582.

Kawauchi, S. AND Suzuki, T. (1968): Abst. 88 th Ann. Meeting Pharm. Soc. Japan, Tokyo, Pharmaceutical Society of Japan, University of Tokyo, Tokyo, p 400.

Maroux, S., Puigserver, A., Dlouha, V., Desnuelle, P., DE HaAs, G. H., Bonsen, P. P. M., Nieuwenhuizen, W. AND VAN Deenen, L. L. M. (1969): Amino Acid Sequence of Phospholipase A from Porcine Pancreas. Biochim. "Biophys. Acta, 188, 353.

Matsuo, H., Fujimoto, Y. Tatsuno, T. (1966): A Novel Method for the Determination of C-terminal Amino Acid in Polypeptides by Selective Tritium Labelling. Biochem. Biophys. Res. Commun., 22, 69.

Titani, K. And Narita, K. (1964): Amino Acid Sequence of Eighteen Peptides isolated from the Tryptic Hydrolysate of Baker's Yeast Cytochrome C. J. Biochem., 56, 241.

WANG, S-S. AND CARPenter, F. H. (1965): A Compositional Assay for Insulin applied to a Search for "Proinsulin". J. Biol. Chem., 240, 1619.

\title{
ACTION OF TRIMERESURUS FLAVOVIRIDIS VENOM ON THE MICROCIRCULATORY SYSTEM OF RAT; DYNAMIC ASPECTS AS REVEALED BY CINEPHOTOMICROGRAPHIC RECORDING
}

\author{
AkIRA OHSAKA*, Makoto OHASHI**, Masaharu TSUCHIYA***, \\ YUKIYOSHI KAMISAKA*** AND YASUO FUJISHIRO**** \\ * The 2nd Department of Bacteriology and ** the 1st Department of \\ Bacteriology, National Institute of Health, Shinagawa-ku, Tokyo 141, \\ Japan, *** Department of Internal Medicine, Keio University School \\ of Medicine, Shinjuku-ku, Tokyo 160, Japan, and **** Department of \\ Surgery, Tokyo Denryoku Hospital, Shinjuku-ku, Tokyo 160, Japan
}

\section{INTRODUCTION}

Hemorrhage is one of the most striking local symptoms evoked by the parenteral injection of crotalid and viperid venoms (Boquet, 1964; Ohsaka et al., 1966; Jiménez-Porras, 1968). Houssay (1930) and others (Porges, 1953; Slotta, 1955; Kaiser and Michl, 1958) ascribed the hemorrhage to the action of proteolytic enzyme(s) in the venom. Recently we have highly purified two immunologically distinct hemorrhagic principles, HR 1 and HR 2, in the venom of Trimeresurus flavoviridis and demonstrated that these hemorrhagic principles and proteolytic enzymes are separate entities (Takahashi and Ohsaka, $1970 \mathrm{a} ; 1970 \mathrm{~b}$; OmoriSatoh and Ohsaka, 1970; Ohsaka et al, 1970).

The preliminary observation made by us demonstrated that the early effects 
of the crude venom as well as partially purified preparations of HR 1 and HR 2 on the microcirculatory system of the mouse mesentery are characterized by severe vasoconstriction, followed by vasodilatation, of arterioles as well as venules, and subsequent hemorrhage in capillary bed (Ohsaka, 1968).

By means of cinephotomicrographic recording we have recently analyzed more in detail the effects of the crude venom on the microcirculatory system of the omentum and the mesentery of rat and have confirmed the above-described observation. We have further demonstrated that in the early stage of the events the erythrocytes oozed out one by one through the pin-point holes formed on the true capillaries including the thoroughfare ways. In the later stage, however, the hemorrhage occurred also from the arterioles and the venules. There was no sign of increased vascular permeability prior to the onset of the oozing of erythrocytes, and even in the course of the events except at the pin-point holes.

The cinephotomicrographic record of these observations is presented at this Symposium*. This report describes briefly the effects of the crude venom on the microcirculatory system of rat at the microscopic level. The possible mechanism of the hemorrhage caused by the venom principles is also discussed. The full details will be communicated elsewhere.

\section{MATERIALS AND METHODS}

Male rats of Wistar strain, weighing 150-200 g, were anesthesized by intraperitoneal injection with Nembutal (pentobarbital sodium) in a dose of about $50 \mathrm{mg}$ per $\mathrm{kg}$ body weight. A midline incision was made on the depilated abdominal skin under local anesthesia with $0.5 \%$ Xylocaine (lidocaine hydrochloride). The omentum or the mesentery was pulled out of the peritoneal cavity. To keep it humid, the tissue exposed over a glass plate was partly covered with pieces of cotton soaked with a Ringer's solution containing $1 \%$ gelatin. Instruments for microscopic observation were set up in a chamber maintained at $37 \mathrm{C}$. Prior to application of a venom sample, the microcirculation in the tissue was carefully inspected to ascertain the absence of any abnormality (Tsuchiya et al., 1969).

In most experiments, a droplet of $0.25 \%$ venom dissolved in the Ringer's solution was applied to the tissue; in some experiments the same sample was topically applied to a very limited region of the tissue by the aid of a cotton fiber. Increased vascular permeability was tested by extravasation of an indicator dye, Pontamine Sky Blue 6 B (4\% in saline), administered through a polyethylene canule inserted into the jugular vein.

Microscopic observations were carried out with magnifications of 40 to $500 \times$ and transillumination with a Xenon light source. With high magnifications (200 to $500 \times$ ) water immersion objectives were used. For high-speed cinephotomicrographic recording, a high-speed-16mm-movie camera, model HIMAC $16 \mathrm{M}$ (Hitachi Ltd, Tokyo, Japan), was employed.

\section{RESULTS AND DISCUSSION}

The vascular effects of a $0.25 \%$ crude venom solution topically applied to the omentum or the mesentery of rat were studied by means of motion-picture

* 17th Symposium on Toxin held in Hakone, July 14-15, 1970. 

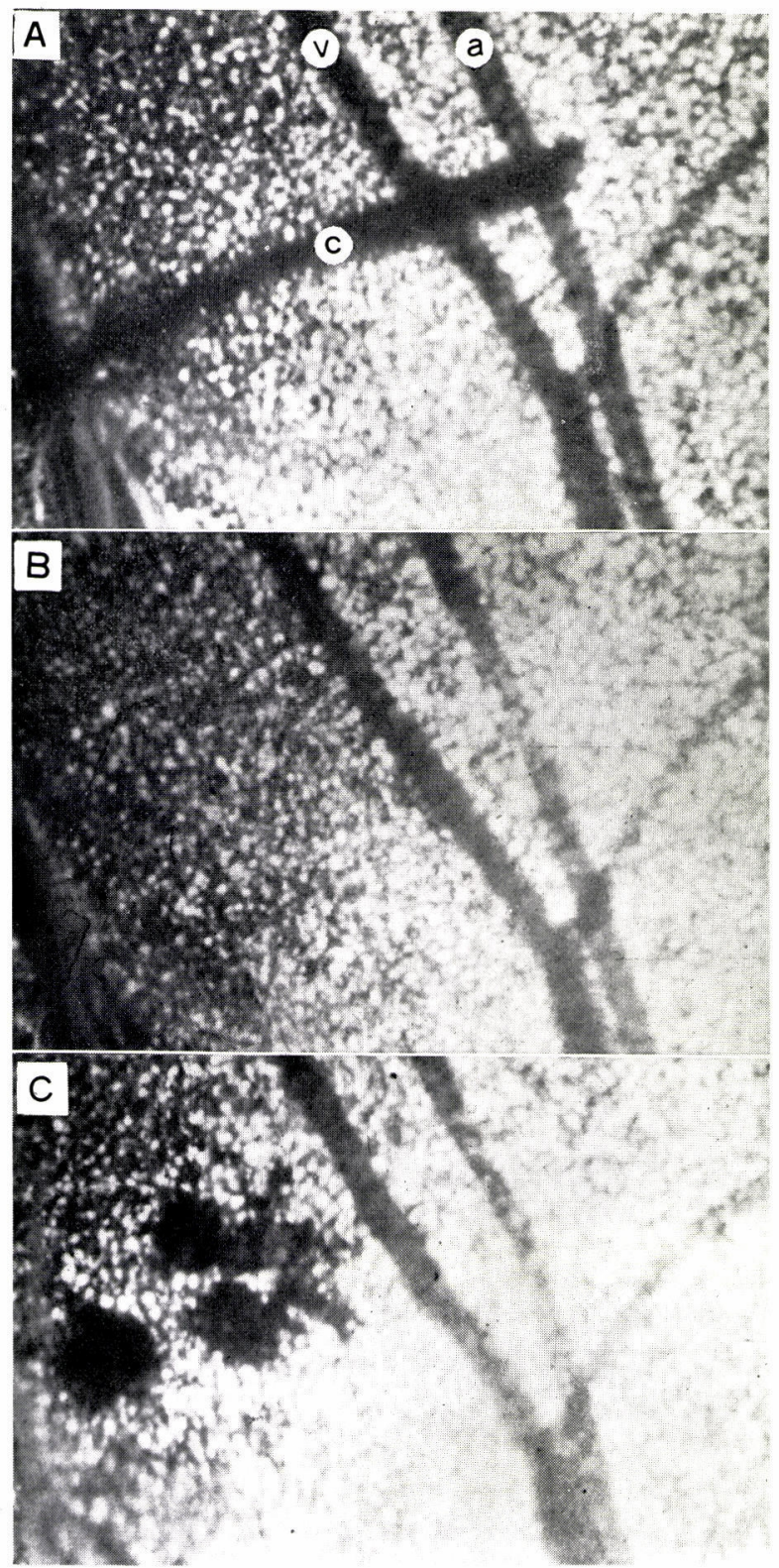

Fig. 1. Vascular effects of Trimeresurus flavoviridis venom applied to rat omentum. In $A$, arteriole (a) and venule (v), both $300 \mu$ in diameter, are shown before application of $0.25 \%$ venom by the aid of a cotton fiber (c). In B, 3 min after application of venom, severe vasoconstriction is found $(40 \times)$ ). In C, 7 min after application, hemorrhage is seen in the capillary region exposed to venom. Vasoconstriction of the arteriole is still seen.

All these pictures were reproduced from cinephotomicrographic record. 
recording through microscope with low magnification $(40 \times)$. Three minutes after application of venom, there occurred severe vasoconstriction of larger vessels (for example, 200-300 $\mu$ in diameter), especially of arterioles (Fig. 1A and Fig. $1 \mathrm{~B})$. Shortly after, this was followed by vasodilatation. These vasomotional changes were usually repeated. In $7 \mathrm{~min}$, hemorrhage occurred from the capillary bed (Fig. 1 C).

To visualize the whole process of the oozing of erythrocytes from the microcirculatory system, observation was made at higher magnifications (200 to $500 \times$ ) with both low- and high-speed movie cameras. We demonstrated that in the early stage of the events the erythrocytes were spurting one by one through the pin-point holes formed on true capillaries including thoroughfare ways, but without apparent rupture of the endothelium. The extravasation of erythrocytes ceased temporarily within seconds after initiation, but with seldom formation of a white thrombus (a platelet plug) which is known as one of the major factors in hemostasis resulting from experimental damage to the vessel wall. Some other factor(s) must be concerned, therefore, with cessation of the erythrocytic extravasation. In this manner, erythrocytes oozed out intermittently through the same pin-point holes. In the later stage the hemorrhage occurred also from the arterioles and venules. The extravasated erythrocytic masses varied in size from a very few cells to large numbers forming petechiae visible macroscopically. We often found the segmentally distended endothelial sheath of venule, inside which a number of erythrocytes had accumulated. Whether or not this phenomenon is related to the hemostatic mechanism remains to be resolved.

Surprisingly, there was no sign of increased vascular permeability, as demonstrated by the use of an indicator dye, prior to the onset of the oozing of erythrocytes and even in the course of the events except at the pin-point holes. This has been confirmed with our purified hemorrhagic principle, HR 1 (Omori-Satoh and Ohsaka, 1970), by Just et al. (1970) who used ${ }^{125} \mathrm{I}$-labeled albumin and ${ }^{51} \mathrm{Cr}$ labeled erythrocytes to distinct between the increased vascular permeability and the hemorrhage.

Thus the early effects of Trimeresurus flavoviridis venom on the microcirculatory system are characterized by severe vasoconstriction, followed by vasodilatation, of larger vessels especially of arterioles, and subsequent oozing of erythrocytes through the pin-point holes formed on the true capillaries including the thoroughfare ways. The venom hemorrhagic principles may act primarily on the muscle cells of a larger vessel or on the nerve cell controlling the function of the muscle cells, resulting in constriction of this vessel (Ohsaka, 1970). It does not seem very likely, however, that the vasomotional changes are the direct cause of the subsequent hemorrhage from the capillaries.

The similar vasoconstriction has been described by Fulton et al. (1956) with Agkistrodon piscivorus piscivorus venom and also by Sagara (1960) with Trimeresurus flavoviridis venom. The mechanism of petechial formation in the cheek pouch with the moccasin venom has been investigated in detail by Fulton et al. (1956) using a high power microscopy and motion picture recording. In accordance with our observation, they demonstrated that red cells spurt one by one through the vessel wall, but without detectable openings in the vessel wall. In contradiction with our finding, however, they described petechial formation occurring 
consistently on the venous portion of the circulation, especially at venous junctions and non-vulnerability of the capillaries.

Recently we have demonstrated that venom hemorrhagic principles exert no cytopathic (or cytotoxic) effect on animal cells cultivated in vitro (Yoshikura et al. 1966; Ohsaka et al., 1966; Ohsaka, 1968) and that the purified principles are either almost free (Omori-Satoh and Ohsaka, 1970) or completely devoid (Takahashi and Ohsaka, $1970 \mathrm{~b}$ ) of proteolytic activity. Together with these findings, the present observation at the microscopic level will provide an important clue for elucidating the physiological mechanism involved in oozing of erythrocytes from the microcirculatory system.

For full understanding of the mechanism, one must clarify at both biochemical and morphological levels how the erythrocytes go out across the lining endothelial cells and also the basement membrane (Ohsaka, 1970). Electron-microscopic study on the vascular endothelial cells treated with the venom is being in progress.

Because of their highly specific vascular effects, the purified venom principles will provide a valuable tool for elucidating the mechanism of oozing of erythrocytes and also soluble components from the microcirculatory system.

Acknowledgement - The authors thank Dr. H. Yoshikura of National Institute of Health, Tokyo for carrying out the preliminary experiments with mouse.

\section{REFERENCES}

Boquet, P. (1964): Venins de serpents — lère Partie. Physio-pathologie de l'envenimation et propriétés biologiques des venins. Toxicon, 2, 5-41.

Fulton, G. P., Lutz, B. R., Shulman, M. H. AND AREndt, K. A. (1956): Moccasin venom as a test for susceptibility to petechial formation in the hamster. In "Venoms" (ed. E. E. Buckley, N. Porges), lst Ed., p.303-310, American Association for the Advancement of Science, Washington.

Houssay, B. A. (1930): Classification des actions des venins de serpents sur l'organisme animal. Compt. Rend. Soc. Biol., 105, 308-310.

JIMÉNEZ-PORRAS, J. M. (1968): Pharmacology of peptides and proteins in snake venoms. Ann. Rev. Pharmacol., 8, 299-318.

Just, D., Urbanitz, D. AND HabermanN, E. (1970): Pharmakologische Charakterisierung der vasculären Schrankenfunktion gegenüber Erythrocyten und Albumin. Naunyn-Schmiedebergs Arch. Pharmak., 267, 399-420.

KAISER, E. AND Michl, H. (1958): Die Biochemie der tierischen Gifte, 1st. Ed., p. 134222, Franz Deuticke, Wien.

Ohsaka, A., Omori-Satoh, T., Kondo, H., Kondo, S. ANd Murata, R. (1966): Bioch-

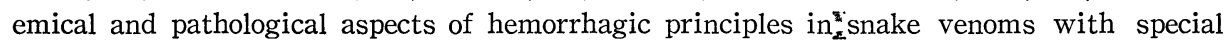
reference to Habu (Trimeresurus flavoviridis) venom. Mem. Inst. Butantan Sâo Paulo, 33, 193-205.

OHSAKA, A. (1968): Hemorrhagic principles and hemolysins of bacterial and animal origin; their chemical nature and biological functions. Protein Nucleic Acid Enzyme, 13, 10071025 .

OHSAKA, A. (1970): Hemorrhagic principles of the venom of Trimeresurus flavoviridis; their chemical nature and biological functions. J. Japan Med. Assoc., 64, 1246-1253.

Ohsaka, A., TAKahashi, T., OMORI-Satoh, T. AND Murata, R. (1970): Purification and characterization of the hemorrhagic principles in the venom of Trimeresurus flavoviridis. Proceedings of the 2nd International Symposium on Animal and Plant Toxins, Tel-Aviv, February 22-28, 1970, in press. 
OMORI-SATOH, T. AND OHSAKA, A. (1970): Purification and some properties of hemorrhagic principle 1 in the venom of Trimeresurus flavoviridis. Biochim. Biophys, Acta, 207, 432-444.

PORGES, N. (1953): Snake venoms, their biochemistry and mode of action. Science, 117, $47-51$.

SAGARA, Y. (1960): Studies on the effect of Trimeresurus flavoviridis venom on peripheral vessels. J. Kagoshima Medical School, 12, 1064-1077.

Slotta, K. H. (1955): Chemistry and biochemistry of snake venoms. Progr. Chem. Org. Nat. Prod., 12, 406-465.

TAKAHASHI, T. AND OHSAKA, A. (1970 a): Purification and characterization of a proteinase in the venom of Trimeresurus flavoviridis. Complete separation of the enzyme from hemorrhagic activity. Biochim. Biophys. Acta, 198, 293-307.

TAKAhAShI, T. AND OHSAKA, A. $(1970 \mathrm{~b})$ : Purification and some properties of two hemorrhagic principles (HR2a and HR2b) in the venom of Trimeresurus flavoviridis; Complete separation of the the principles from proteolytic activity. Biochim. Biophys. Acta, 207, 65-75.

Tsuchiya, M., Fuzishiro, Y. AND Shishido, T. (1969): Observation vitale de la thrombogénèse. In "Atherogenesis" (ed. T. Shimamoto, F. Numano), lst Ed., p. 145-150, Excerpta Medica Foundation, Amsterdam.

Yoshikura, H., Ogawa, H., OHSAKa, A. AND OMORI-SATOH, T. (1966): Action of Trimeresurus flavoviridis venom and the partially purified hemorrhagic principles on animal cells cultivated in vitro. Toxicon, 4, 183-190.

\title{
THE MODE OF BINDING OF SUGARS TO RICIN PROTEIN
}

\author{
Shigeru NANNO, MAsatsune ISHIGURO, Gunki FUNATSU \\ AND MASARU FUNATSU
}

Laboratory of Biochemistry, Faculty of Agriculture, Kyushu University, Fukuoka, Japan

It was reported previously that ricin has a molecular weight of about 60,000 and is composed of two different subunits, Ala-chain and Ile-chain, each of which has a molecular weight of 30,000 (Ishiguro et al., $1964 \mathrm{~b}$; Funatsu et al., 1970).

We also reported that ricin contains about $5.6 \%$ of mannose and about $2 \%$ of glucosamine, probably N-Ac-glucosamine (Funatsu et al., 1970).

In order to clarify the mode of binding of these sugars to ricin protein, attempts were made to obtain glycopeptides from both subunits and to investigate the structure of glycopeptides obtained.

Ricin was prepared from castar bean by a modification of the method of Ishiguro et al (1964 a). Ricin was reduced by $\beta$-mercaptoethanol in the absence of urea. The reduced ricin was carboxymethylated with monoiodoacetic acid. Then, the reduced and carboxymethylated ricin (RoCM-ricin) was separated into subunits by DEAE-cellulose column chromatography. In this chromatography Ala-chain was obtained in high purity. On the one hand, a little amount of ricin which was not modified and remained intact and of the separated Alachain were eluted in the Ile-chain fraction. This fraction was employed as crude Ile-chain throughout this experiment without further purification. 
The Ala-chain and the Ile-chain were separately suspended in a little amount of water and diluted to the final concentration of $0.5 \%$. Digestion was carried out with a $1 / 100$ amount of nagarse at $37 \mathrm{C}$ and $\mathrm{pH} 8.0$ for $65 \mathrm{hr}$. The digest was concentrated under reduced pressure and applied onto a column $(1.8 \times 200 \mathrm{~cm})$ of Sephadex G-25 and eluted with water. The fractions containing sugar were combined, liophylized and dissolved in $1 \mathrm{ml}$ of $2 \%$ aqueous pyridine and then applied onto a column $(1 \times 100 \mathrm{~cm})$ of Dowex $1 \times 2\left(\mathrm{CH}_{3} \mathrm{COO}^{-}\right.$form $)$equilibrated with $2 \%$ pyridine. After elution with $250 \mathrm{ml}$ of $2 \%$ pyridine, a liner gradient elution was continued with each $200 \mathrm{ml}$ of $2 \%$ pyridine and 0.025 (in the case of Ala-chain) or $0.02 \mathrm{~N}$ acetic acid (in the case of crude Ile-chain). As the results, three glycopeptide fractions, Ala-N-1, -2 and -3 , were obtained from Ala-chain and four fractions, crude Ile-N-1, $-2,-3$ and -4 , from crude Ile-chain.

The amino acid and sugar compositions of each glycopeptide were analysed and shown in Table 1. As can be seen in Table 1 the amino acid and sugar compositions of each crude Ile-N-1, -2 and -3 were similer to that of Ala-N-1, -2 and -3 respectively. In addition, the yields of the formers were extremely low compared

Table 1. Amino acid and sugar compositions of glycopeptides

Amino acid and glucosamine were analysed by amino acid analyzer after hydrolysis with constant boiling point-hydrochloric acid (in the case of amino acid) or $4 \mathrm{~N}$ hydrochloric acid (in the case of glucosamine). Mannose was analysed by phenol-sulfric acid method (Dubois et al., 1956)

\begin{tabular}{llllllll}
\hline & Ala-N-1 & -2 & -3 & crude Ile-N-1 & -2 & -3 & -4 \\
Asp & $3.00(3)$ & $3.00(3)$ & $2.00(2)$ & $3.00(3)$ & $3.00(3)$ & $2.00(2)$ & $1.00(1)$ \\
Thr & $0.98(1)$ & $0.95(1)$ & $0.93(1)$ & $0.90(1)$ & $0.93(1)$ & $0.91(1)$ & \\
Glu & & & $0.93(1)$ & & & $1.01(1)$ & $0.96(1)$ \\
Pro & $0.98(1)$ & $0.92(1)$ & $0.93(1)$ & $1.06(1)$ & $1.16(1)$ & $1.13(1)$ & $0.99(1)$ \\
Gly & $1.19(1)$ & $1.08(1)$ & & $1.20(1)$ & $1.11(1)$ & & \\
Ile & 1.48 & 1.57 & & $1.20(1)$ & $2.15(2)$ & & $1.01(1)$ \\
Phe & & & $0.91(1)$ & & & $0.92(1)$ & $0.97(1)$ \\
Arg & $1.16(1)$ & $1.04(1)$ & & $1.16(1)$ & $1.16(1)$ & & \\
glucosamine & $1.82(2)$ & $1.78(2)$ & $1.80(2)$ & $1.94(2)$ & $2.00(2)$ & $1.78(2)$ & $1.75(2)$ \\
mannose & $6.21(6)$ & $6.32(6)$ & $6.83(7)$ & $6.16(6)$ & $5.96(6)$ & $6.84(7)$ & $3.79(4)$ \\
Yield $(\mu \mathrm{M})$ & 0.96 & 0.57 & 1.79 & 0.40 & 0.51 & 0.86 & 2.58 \\
\hline
\end{tabular}

with that of crude Ile-N-4. From these evidences it was inferred that the crude Ile-N-1, -2 and -3 resulted from Ala-chain was contaminated with crude Ile-chain fraction. Thus, crude Ile-N-4 was regarded as unique glycopeptide derived from Ile-chain. On the other hand, N-1 had similar amino acid and suger compositions to $\mathrm{N}-2$ and sum of the yield of both glycopeptides coincided well with that of $\mathrm{N}-3$. This suggested that $\mathrm{N}-1$ and $\mathrm{N}-2$ might have originated from the same moiety of the Ala-chain.

$\mathrm{N}-1, \mathrm{~N}-2, \mathrm{~N}-3$ and $\mathrm{N}-4$ were then subjected to further digestion with pronase; each glycopeptide disolved in $10 \mathrm{ml}$ of water was digested with a $1 / 40$ amount of pronase at $37 \mathrm{C}$ and $\mathrm{pH} 7.8$ for $48 \mathrm{hr}$. The glycopeptides produced were separated through Sephadex G-25. Table 2 shows the amino acid and sugar compositions of these peptides separated. Obviously from Table 2, both $\mathrm{N}-1$ and $\mathrm{N}-2$ resulted 
Table 2. Amino acid and sugar compositions of glycopeptides yielded after digestion with pronase

\begin{tabular}{lrrrr}
\hline origin & $\mathrm{N}-1$ & $\mathrm{~N}-2$ & $\mathrm{~N}-3$ & $\mathrm{~N}-4$ \\
\hline after digestion & \multicolumn{2}{c}{$\mathrm{P}-1$} & $\mathrm{P}-2$ & $\mathrm{P}-3$ \\
\hline Asp & $2.00(2)-\#$ & $2.00(2)-$ & $2.00(2)$ & $1.00(1)$ \\
Thr & $0.92(1)$ & $0.94(1)$ & $0.89(1)$ & - \\
Glu & & & $0.95(1)$ & - \\
Pro & - & - & $0.96(1)$ & \\
Gly & $1.21(1)$ & $1.09(1)$ & & $0.67(1)$ \\
Ile & - & - & & $0.66(1)$ \\
Phe & - & - & & \\
Arg & $1.84(2)$ & $1.50(2)$ & $1.96(2)$ & $1.76(2)$ \\
glucosamine & $5.99(6)$ & $5.79(6)$ & $6.81(7)$ & $4.26(4)$ \\
mannose & &
\end{tabular}

\#-indicate the amino acid cut off from original glycopeptides

in the identical glycopeptide, P-1. Thus, it was concluded that $\mathrm{N}-1$ and $\mathrm{N}-2$ originated from the same moiety of Ala-chain. On the other hand. N-3 resulted in P-2 and N-4 in P-3. Consequentry, two glycopeptides, P-1 and P-2, were derived from Ala-chain and one from Ile-chain. Thus, it was evidented that sugars in ricin are located in three sites of the molecule, two in Ala-chain and one in Ile-chain, where sugar moieties are linked to protein as oligosaccharide.

In order to determine the amino acid which linked with sugar the sequential analysis of these glycopeptides was carried out.

The subtractive Edman degradation of $\mathrm{P}-1$ glycopeptide revealed that the amino acid sequence of this peptide was Asx-Asx-Gly-Thr. Thr was recovered almost quantitatively even after the alkali-treatment in which glycopeptide was allowed to stand in $0.5 \mathrm{~N}$ sodium hydroxide at $4 \mathrm{C}$ for $22 \mathrm{hr}$. Therefore, it became evident that no sugar is linked to Thr, since it is well known that $\mathrm{Thr}$ or Ser linked with sugar is decomposed during such alkali-treatment. Having no functional group, Gly was also considered not to be linked with suger. So, sugars are supposed to be linked to either one of the two Asx or both. On the one hand, new glycopeptide fraction having composition $\mathrm{Asp}_{1 \cdot 11} \mathrm{Thr}_{0.95} \mathrm{Gly}_{1 \cdot 10}$ glucosamine $_{1.56}$ mannose $_{6.00}$ was obtained by gel filtration of the aqueous layer of the first Edman degradation product of P-1. It was, therefore, presumed that sugars were linked to Asx located at second position from $\mathrm{N}$-terminal and hence the structure of P-1 was elucidated to be Asx-Asx (sugar)-Gly-Thr.

The amino acid composition of P-2 was $\mathrm{Asp}_{2} \mathrm{Thr}_{1} \mathrm{Glu}_{1} \mathrm{Pro}_{1}$. The data of subtractive Edman degradation showed the $\mathrm{N}$-terminal and the next amino acid to be both Asx, whereas no further sequential information was obtained. Thr of this glycopeptide was also recovered without loss after alkali-treatment. Thus, sugars were supposed to be linked to either Asx or Glx. On the other hand, two components, P-2-A and P-2-B, were obtained from the aqueous layer of the first Edman degradation product by gel filtration through Sephadex G-25. The aqueous solution of P-2-A showed a UV-spectrum having maximum absorption at $263 \mathrm{~m} \mu$, which was considered to be derived from PTH-Asx. The composition 
of P-2-A was shown to be PTH-Asx ${ }_{0.99}$ glucosamine $_{1.89}$ mannose $_{6.00}$ where PTHAsx was calculated from optical density at $263 \mathrm{~m} \mu$. Thus, it was assumed that the sugar moiety was linked to N-terminal Asx: PTH-Asx (sugar). P-2-B was shown to possess no sugar and the amino acid composition was $\mathrm{Asp}_{1.00} \mathrm{Thr}_{0.91}$ $\mathrm{Glu}_{1.02} \mathrm{PrO}_{0.99}$. Its amino acid sequence was elucidated by subtractive Edman degradation to be Asx-Thr-Glx-Pro. These observations supported the following structure of P-2 glycopeptide: Asx (sugar)-Asx-Thr-Glx-Pro.

In P-3 glycopeptide sugars seemed to be linked to Asx, because no other functional group was found in this peptide. The subtractive Edman degradation of P-3 revealed that the amino acid sequence of P-3 was Ile-Asx-Phe. Thus, the structure of P-3 glycopeptide was concluded to be Ile-Asx (sugar) -Phe.

\title{
REFERENCES
}

Dubois, M., Gilles, K. A., Hamilton, J. K., Rebers, P. A. And Smith, F. (1956): Colorimetric method for determination of sugars and related substances. Anal. Chem., $28,350-356$.

Funatsu, G., Ishiguro, M., NANno, S. AND Funatsu, M. (1970): Studies on chemical structure of ricin, toxic protein contained in castar bean seed. Japan. J. Med. Sci. Biol., 23, 264-267.

Ishiguro, M., TAKahashi, T., Funatsu, G., Hayashi, K. And Funatsu, M. (1964 a): Biochemical studies on ricin. I. Purification of ricin. J. Biochem. Tokyo, 55, 587-592.

Ishiguro, M., TAKahashi, T., Hayashi, K. AhD Funatsu, M. (1964 b): Biochemical studies on ricin. II. Molecular weight and some physicochemical properties of crystalline ricin D. J. Biochem. Tokyo, 56, 325-327.

\section{SITE OF ACTION OF CORD FACTOR IN MITOCHONDRIA}

\author{
MASAHIKO KATO \\ Research Institute of Tuberculosis, Toneyama Hospital, \\ National Sanatorium, Toyonaka, Osaka 560
}

Cord factor, a toxic glycolipid of Mycobacterium tuberculosis, induced in vivo a fragmentation of the mitochondrial membrane and inhibited the phosphorylation associated with the aerobic oxidation of succinate in mouse liver mitochondria (Kato, 1968). The site of this metabolic lesion by cord factor was assumed to be located on the mitochondrial electron transport chain between cytochrome $b$-coenzyme Q complex and cytochrome $c$ (Kato, 1966, 1967, 1968) and on coupling site II of the mitochondrial oxidative phosphorylation (Kato, 1967). It has been also demonstrated that the respiratory enzymes and phosphorylative activity in mouse liver were markedly impaired by living virulent infection with M. tuberculosis (Kato, 1966 and 1967). In an attempt to pinpoint

An original paper of this abstract was published in Arch. Biochem. Biophys., 140, 379-390, 1970. 
the site of action of cord factor in mitochondria, an in vitro system to test the effect of cord factor on the mitochondrial function was developed. In this report, mitochondrial suspension was preincubated. with an aqueous suspension of cord factor and it was demonstrated that cord factor directly affected the mitochondrial oxidative phosphorylation at coupling site II and caused a loss of respiratory control with succinate and a number of NADH-linked substrates.

Male mice of random-bred ddO stock were obtained from a closed colony in the Laboratory Animals' Center of Osaka University, Osaka, and were used at 4 to 6 weeks of age. Rats (Wister strain, female), guinea pigs, rabbits and chicken were also used.

Cord factor, mycolic acid and acetylated cord factor were prepared from live cultures of virulent human tubercle bacilli $\mathrm{H} 37 \mathrm{Rv}$ as previously reported (Kato, 1968). Methyl 6-(3', x-sulphitomycolanoyl)- $\alpha$-D-glucoside, 6-(3'-acetoxy, xmethoxymycolanoyl)-N-acetyl-D-glucosamine and 6, x-di-(3'-acetoxy, x-methoxymycolanoyl)-N-acetyl-D-glucosamine were obtained from Dr. Jean Asselineau, Laboratoire de Chimie biologique de la faculte des Sciences de Toulouse, Toulouse, France. ${ }^{14} \mathrm{C}$-labeled cord factor was prepared from $\mathrm{H} 37 \mathrm{Rv}$ cultured in Sauton media containing $0.3 \mu \mathrm{ci}$ per $\mathrm{ml}$ of $\mathrm{U}^{-14} \mathrm{C}$-sodium acetate (specific activity: 22.2 mci per $\mathrm{mM}$ ). Cord factor was suspended in water by a modification of the previously reported method. Sucrose and Tris-chloride $(0.2 \mathrm{M}, \mathrm{pH} 7.6)$ were added to the aqueous cord factor suspension to give the final concentration of $0.25 \mathrm{M}$ and $0.01 \mathrm{M}$ at $\mathrm{pH}$ 7.4, respectively. Mitochondria from liver were prepared according to Hogeboom (1955) and suspended in a final volume of 1.0 $\mathrm{ml}$ of sucrose-Tris medium per gram (fresh weight) of liver.

Phosphorylation coupled to the oxidation of succinate and a number of NADH-linked substrates was assayed in a reaction system containing in a final volume of $3.0 \mathrm{ml}: 125 \mathrm{mM}$ sucrose, $17 \mathrm{mM}$ potassium phosphate ( $\mathrm{pH} \mathrm{7.4),} 13.6$ $\mu \mathrm{M}$ cytochrome $c$ (type VI from Sigma Chemical Co., St. Louis, Mo., U. S. A.), 2.5 $\mathrm{mM}$ ADP, $20 \mathrm{mM}$ glucose, $1 \mathrm{mg}$ (150 K. M. units) of hexokinase, $6.7 \mathrm{mM} \mathrm{MgCl}_{2}$, $5 \mathrm{mM} \mathrm{KF}, 10 \mathrm{mM}$ substrate and 3 to $10 \mathrm{mg}$ mitochondrial protein. When succinate was used as substrate, the reaction system contained $0.1 \mu \mathrm{M}$ rotenone (K \& K Laboratories, Plainview, N. Y., U. S. A.) in addition to the above components. Oxygen uptake was measured at $25 \mathrm{C}$ for 15 to $20 \mathrm{~min}$ and inorganic phosphate was determined by the Fiske-Subbarow procedure (Fiske and Subbarow, 1925).

Phosphorylation at coupling site II was assayed by a slight modification of the method of Lee et al. (1967). The efficiency of phosphorylation was expressed as $\mathrm{P} / 2 e^{-}$(ratio of moles of inorganic phosphate esterified to 2 moles of ferricyanide reduced).

Phosphorylation associated with the oxidation of cytochrome $c$ (site III phosphorylation) was assayed by the method of Sanadi and Jacobs (1967). Sodium ascorbate $(6.7 \mathrm{mM})$ and $250 \mu \mathrm{M} \mathrm{N}, \mathrm{N}, \mathrm{N}$, N'-tetramethyl-p-phenylenediamine (TMPD) was used as substrate in the presence of $0.1 \mu \mathrm{M}$ rotenone in the reaction system.

Mitochondrial ATPase was assayed at $25 \mathrm{C}$ in $1.0 \mathrm{ml}$ of reaction mixture containing $50 \mathrm{mM}$ Tris-acetate $(\mathrm{pH} 7.4), 30 \mathrm{mM} \mathrm{KCl}, 5 \mathrm{mM} \mathrm{MgCl}_{2}, 5 \mathrm{mM}$ ATP and 1 to $2 \mathrm{mg}$ mitochondrial protein. The release of inorganic phosphate in the 
deproteinized supernatant was measured by the Fiske-Subbarow procedure.

Results: Cord factor induced a dose-dependent inhibition of oxidative phosphorylation with either succinate or pyruvate+malate as substrate when it was preincubated with the mitochondrial suspension $15 \mathrm{~min}$ at $20 \mathrm{C}$ or $30 \mathrm{~min}$ at $2 \mathrm{C}$. When added in the reaction mixture without preincubation, cord factor did not affect the phosphorylation accompanying the oxidation of both substrates. The respiratory contorol was lost in parall with the decrease in $\mathrm{P} / \mathrm{O}$ ratio by the preincubation of mitochondria with the increasing concentration of cord factor. Cord factor affected only that portion of respiration which coupled to phosphorylation with succinate as substrate, while the oxidation of pyruvate+ malate was inhibited either in the presence or in the absence of phosphate acceptor system. These results indicate that cord factor affected not only the mitochondrial respiration tightly coupled to phosphorylation but the electron transfer process from NADH to oxygen. With mitochondria prepared from the livers of a wide variety of animal species, the maximal decrease of $\mathrm{P} / \mathrm{O}$ ratio with even very high concentration of cord factor was about one phosphorylation unit for the oxidation of succinate and a number of NADH-linked substrates.

In order to determine the site of interaction of cord factor with the mitochondrial electron transport chain, the effect of cord factor on the phosphorylation at coupling sites II and III was next examined. In parallel with the decline of $\mathrm{P} / \mathrm{O}$ ratio for the succinate oxidation (coupling sites II + III), the phosphorylation accompanying the oxidation of succinate by ferricyanide at coupling site II was completely damaged by cord factor, while the oxidation of ascorbate-TMPD and the accompanying phosphorylation at coupling site III remained intact under the action of cord factor (Fig. 1). Since the reduction of ferricyanide by succinate in the cord factor-treated mitochondria was blocked by antimycin A to the same extent as in control mitochondria, the possibility of the leakage of electrons prior to coupling site II was ruled out. Cord factor slightly stimulated the mitochondrial ATPase activity. The effect of cord factor and 2, 4-dinitrophenol to induce the ATPase was additive.

Mycolic acid, acetylated cord factor and a nontoxic cord factor-analogue, 6, $\mathrm{x}$-di-(3'-acetoxy, $\mathrm{x}$-methoxymycolanoyl)-N-acetyl-D-glucosamine were without effect on the mitochondrial respiration and phosphorylation, while two toxic synthetic analogues, methyl 6-(3', x-sulphitomycolanoyl)- $\alpha$-D-glucoside and 6-(3'-acetoxy, $\mathrm{x}$ methoxymycolanoyl)-N-acetyl-D-glucosamine affected the mitochondrial oxidative phosphorylation as did cord factor.

To determine if cord factor binds to a specific site of the mitochondrial membrane system and exerts its inhibitory action after a certain period of preincubation, an aqueous suspension of ${ }^{14} \mathrm{C}$-cord factor was added to the mitochondrial suspension and incubated $15 \mathrm{~min}$ at $20 \mathrm{C}$. Mitochondria were precipitated by a centrifugation at $24,000 \times g$ for $10 \mathrm{~min}$ and washed twice under the same centrifugal condition. Cord factor suspended in sucrose-Tris without mitochondria was not precipitated by the same centrifugal procedure. About 30 per cent of ${ }^{14} \mathrm{C}$-cord factor was found in the first mitochondrial pellet but it was easily washed out by the second and third centrifugation (Table 1). From these results, it was assumed that cord factor was bound to mitochondria very loosely or even not at all and only co-precipitated in the first mitochondrial pellet. 


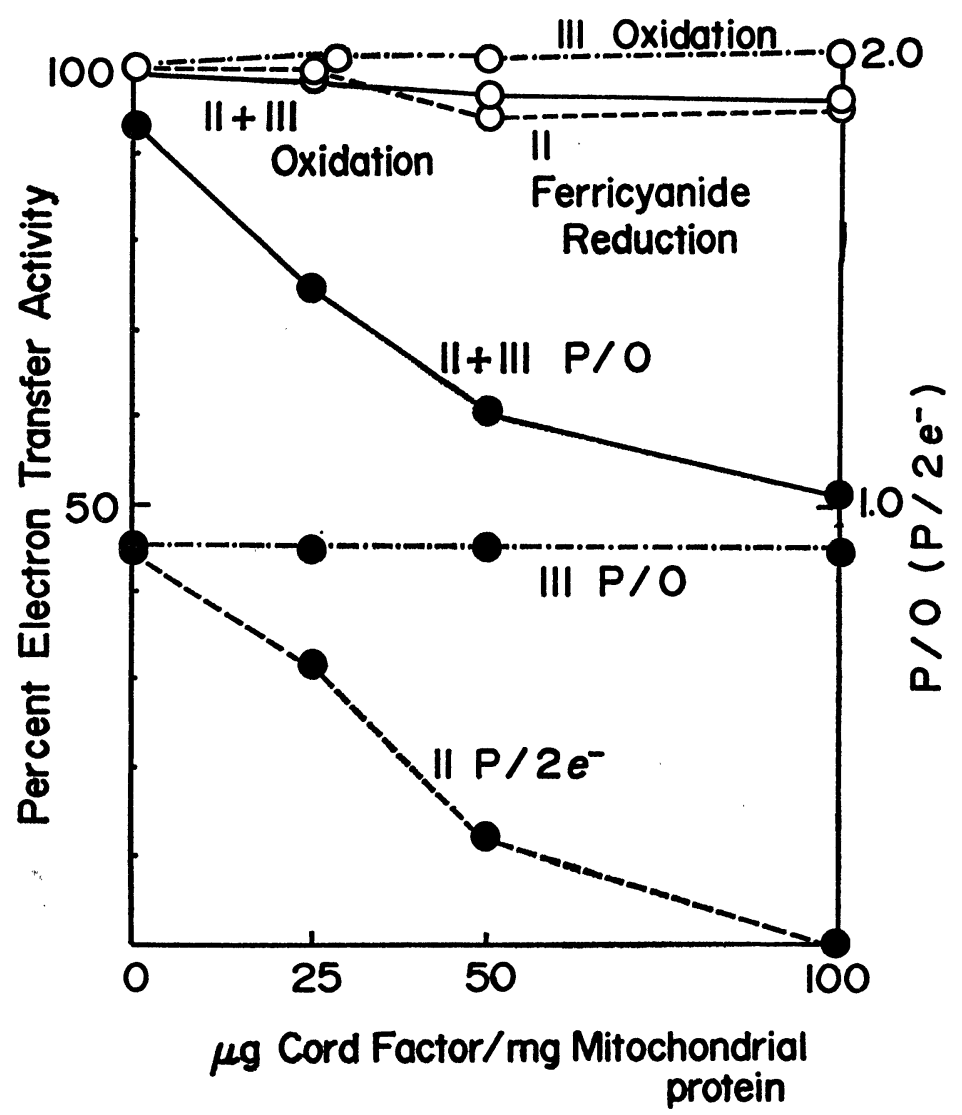

Fig. 1. Effect of cord factor on phosphorylation at coupling site II and III. Mitochondria were preincubated with varying level of cord factor $15 \mathrm{~min}$ at $20 \mathrm{C}$ before addition to the assay medium.

II+III: Oxidation of succinate and accompanying phosphorylation. II: Oxidation of succinate by ferricyanide and accompanying phosphorylation. III: Oxidation of ascorbate-TMPD and accompanying phosphorylation.

Thus, it seems most likely that cord factor disintegrates the mitochondrial membrane by its detergent-like action and impairs the membrane-associated mitochondrial function.

Summary : Cord factor (trehalose-6, 6'-dimycolate), a toxic glycolipid of Mycobacterium tuberculosis, inhibited the phosphorylation associated with the oxidation of either succinate or $\mathrm{NADH}$-linked substrates and caused a loss of respiratory control in mouse liver mitochondria. Preincubation of the mitochondrial suspension with cord factor was necessary for this inhibiotory action of cord factor. Liver mitochondria from a wide variety of animal species were susceptible to the action of cord factor. Site II phosphorylation was completely blocked, while site III phosphorylation was entirely intact under the action of cord factor. Mycolic acid, acetylated cord factor and a nontoxic cord factor-analogue, 6, x-di-(3'acetoxy, x-methoxymycolanoyl)-N-acetyl-D-glucosamine were without 
Table 1. Examination of binding of cord factor to mitochondria

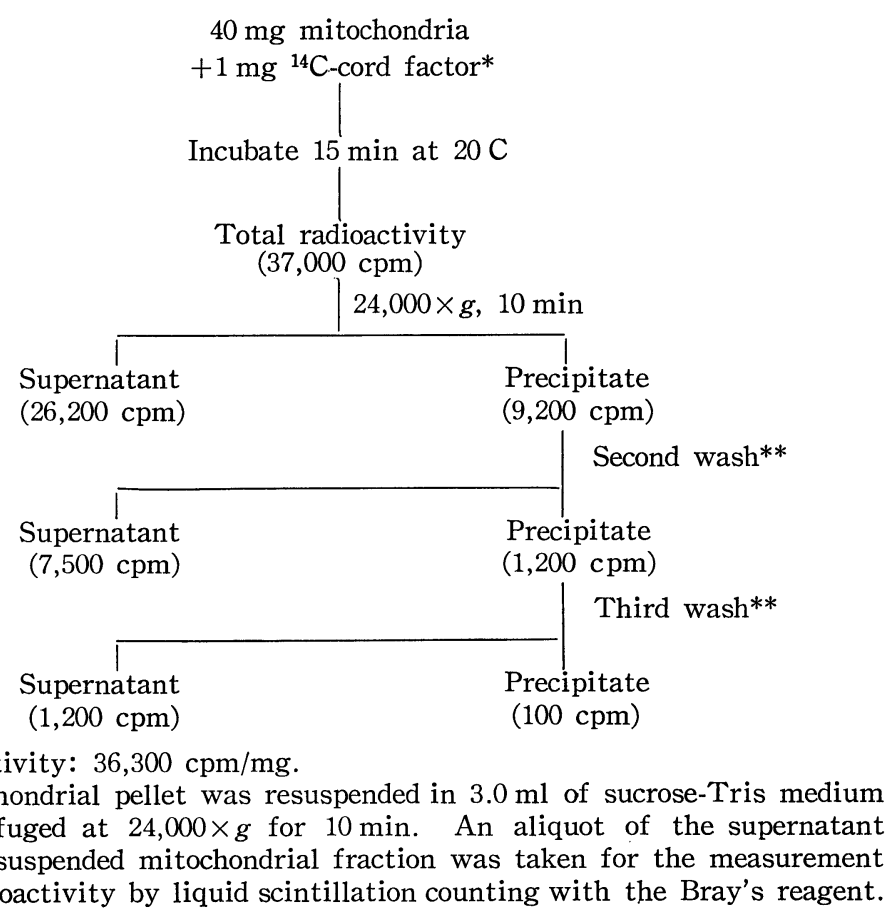

effect, while two toxic cord factor-analogues, methyl 6-(3', x-sulphitomycolanoyl) $-\alpha$-D-glucoside and 6-(3'acetoxy, x-methoxymycolanoyl)-N-acetyl-D-glucosamine, affected the mitochondrial oxidative phosphorylation as did cord factor. Cord factor slightly induced the mitochondrial ATPase. The effect of cord factor and 2, 4-dinitrophenol to stimulate the mitochondrial ATPase was additive. ${ }^{14} \mathrm{C}$ cord factor did not bind tightly to mitochondria. It was concluded from above results that cord factor causes a disintegration of the mitochondrial membrane system by its detergent-like action and affects the membrane-associated respiration and phosphorylation at coupling site II.

\section{REFERENCES}

Fiske, C. H. AND SUBbAROw, Y. (1925): The colorimetric determination of phosphorus. J. Biol. Chem., 66, 375-400.

HOGEвOOM, G. H. (1955): Fractionation of cell components of animal tissues. in "Methods in Enzymology" S. P. Colowick and N. O. Kaplan, eds., vol. 1. Academic Press, Inc., New York, p. 16-19.

KATO, M. (1966): Studies of a biochemical lesion in experimental tuberculosis in mice. III. Site of lesion in electron transport chain. Am. Rev. Respirat. Disease, 94, 388-394. KATo, M. (1967): Studies of a biochemical lesion in experimental tuberculosis in mice. VI. Effect of toxic bacterial constituents of tubercle bacilli on oxidative phosphorylation in host cell. Am. Rev. Respirat. Disease, 96, 998-1008.

KATO, M. (1968): Studies of a biochemical lesion in experimental tubercuolsis in mice. 
VII. Structural and functional damage in mouse liver mitochondria under the toxic action of cord factor. Am. Rev. Respirat. Disease, 98, 260-269.

Lee, C. P., SottocasA, G. L. ANd ERnster, L. (1967): Use of artificial electron acceptors for abbreviated phosphorylating electron transport: Flavin-cytochrome $c$. in "Methods in Enzymology" R. W. Estabrook and M. E. Pullman, eds., vol. 10. Academic Press, Inc., New York, p. 33-35.

SANADI, D. R., AND JACOBS, E. E. (1967): Assay of oxidative phosphorylation at the cytochrome oxidase region (site III). in "Methods in Enzymology" R. W. Estabrook and M. E. Pullman eds., vol. 10. Academic Press, Inc., New York, p. 38-41.

\title{
THE ROLE OF CORD FACTOR IN PATHOGENESIS OF TUBERCULOSIS
}

\author{
MASAHIKO KATO \\ Research Institute of Tuberculosis, Toneyama Hospital, National \\ Sanatorium, Toyonaka, Osaka 560
}

It has been reported in a series of investigations (Kato, 1968 a, b, 1969; Kato, 1970) that cord factor, a toxic glycolipid of Mycobacterium tuberculosis (Noll et al., 1956), induced either in vivo or in vitro a fragmentation of the mitochondrial membrane structure and a functional damage of the membraneassociated respiration and phosphorylation. An indirect evidence of the production of cord factor in vivo by tubercle bacilli was also presented (Kato, 1966). From these findings, it was assumed that cord factor supports the proliferation of tubercle bacilli in vivo by interferring with the basic metabolic activity in host-cell and thus affecting the development of the defense mechanism of host. In order to confirm this proposed hypothesis, mice were vaccinated with a cord factor-methylated bovine serum albumin (MBSA) complex and their response to living virulent infection with $M$. tuberculosis was studied. It is shown in this study that the vaccination with cord factor-MBSA complex protected mice against both the toxicity of cord factor and the infection with tubercle bacilli.

Male mice of random-bred ddO stock (Laboratory Animals' Center of Osaka University, Osaka) were used at 4 to 6 weeks of age. They were maintained as reported previously (Kato, 1968 a). Cord factor, mycolic acid and acetylated cord factor were prepared as described in previous papers (Kato, $1968 \mathrm{a}$ and 1968 b). The aqueous suspensions of these lipids were prepared by a modification (Kato, 1970) of the previously reported method (Kato, 1967). For the injection into mice, cord factor was dissolved in Bayol F (Esso-Standard Oil Co., New York, N. Y., U. S. A.), sterilized by heating at $100 \mathrm{C}$ for $15 \mathrm{~min}$ and injected intraperitoneally into mice. ${ }^{14} \mathrm{C}$-labeled cord factor was prepared as reported previously (Kato, 1970). Bovine serum albumin powder ("Fraction V") was methylated by the method of Mandell and Hershey (1960). To three parts of MBSA dissolved in distilled water was added one part of cord factor suspended in water and the mixture was allowed to stand overnight at $2 \mathrm{C}$. A flocculate 
precipitate was collected by centrifuging at $4,000 \mathrm{rpm}$ for $20 \mathrm{~min}$ in a refrigerated centrifuge. Protein was determined by the Folin phenol reagent (Inoue and Nojima, 1967). Cord factor was determined by using ${ }^{14} \mathrm{C}$-cord factor and measuring the radioactivity by liquid scintillation counting with Bray's solution (Bray, 1960).

The aqueous suspension of cord factor-MBSA complex was emulsified with an equal volume of Freund incomplete adjuvant (Difco Laboratories, Detroit, Michigan, U. S. A.) and injected twice a week for three weeks into mice by the subcutaneous route. One week after the last injection, mice were tested for the protective potency of vaccination. The toxicity of cord factor was tested by repeated intraperitoneal injection of $10 \mu \mathrm{g}$ at 2-day interval or by single injection of the graded amounts from 50 to $500 \mu \mathrm{g}$. 'The fifty per cent lethal dose $\left(\mathrm{LD}_{50}\right)$ was calculated at 14 days by the method of Reed and Muench (1938). Assay of oxidative phosphorylation by mouse liver mitochondria was carried out as previously reported (Kato, 1968). Succinate with $0.1 \mu \mathrm{M}$ rotenone (K \& K Laboratories, Plainview, N. Y., U. S. A.) was used as substrate. The organisms used for infection were: M. tuberculosis (strain H37Rv), Brucella abortus, strain A62 (Given by Dr. K. Kanai, National Institute of Health, Tokyo), Listeria monocytogenes, serotype I (NCTC7973, given by Dr. G. B. Mackaness, Trudeau Institute, Stranac Lake, N. Y., U. S. A.), and Salmonella enteritidis No. II and Salmonella typhimurium LT-2 (Given by Dr. K. Saito, Keio University School of Medicine, Tokyo).

Results: The results of component analysis of cord factor-MBSA complex indicated that the ratio of cord factor to MBSA was $10: 1$. When mycolic acid or acetylated cord factor was substituted for cord factor and bovine serum albumin (BSA) for MBSA, no precipitate was formed even after prolonged storage at $2 \mathrm{C}$. Vaccination with cord factor-MBSA complex emulsified in Freund incomplete adjuvant exerted no harmful effect on mice. As illustrated in Fig. 1, mice vaccinated with cord factor-MBSA complex showed an enhanced resistance to the toxic action of cord factor. The vaccinated mice survived repeated injection of cord factor, while non-vaccinated control mice gradually lost their body weight and died between the first and second week in a highly exhausted state. Vaccinated mice resisted also to one single large dose of cord factor. The $\mathrm{LD}_{50}$ calculated at 14 days was $76 \mu \mathrm{g}$ for the non-vaccinated and larger than $500 \mu \mathrm{g}$ for the vaccinated mice. In close accord to these results, the liver mitochondria prepared from the cord factor-MBSA-vaccinated mice were less affected than those prepared from control mice. The content of protein and the activity of oxidative phosphorylation were maintained normal against in vivo action of cord factor in the vaccinated mouse liver. Fig. 2 shows that the cord factor-MBSA-vaccinated mice were highly resistant to a massive intravenous injection with virulent $M$. tuberculosis $\mathrm{H} 27 \mathrm{Rv}$. Autopsic findings at 30 days after challenge indicated that the macroscopic lesion in the lungs of vaccinated mice was minimal and the number of viable units in the vaccinated mouse lungs was $10^{2}$ to $10^{3}$ less than that in the control mouse lungs. The prevention of the bacterial multiplication in both lungs and spleen was noted during the first three weeks after challenge.

Vaccination with adjuvant by the subcutaneous route or into footpad was 

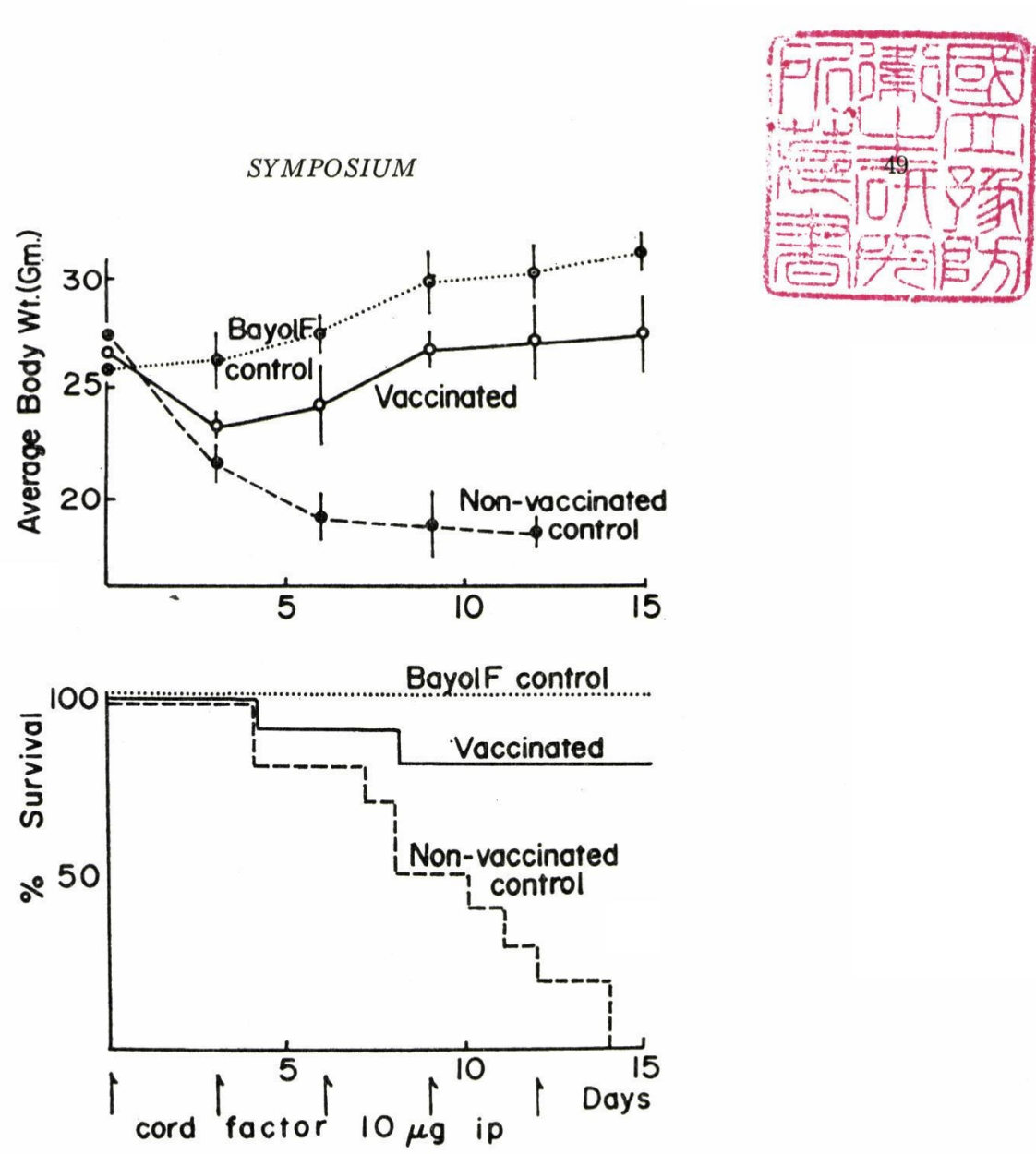

Fig. 1. Effect of repeated intraperitoneal injection of cord factor on mice vaccinated with cord factor-MBSA complex. Ten mice in each group received $0.1 \mathrm{ml}$ of Bayol $\mathrm{F}$ (control) or $10 \mu \mathrm{g}$ of cord factor per $0.1 \mathrm{ml}$ of Bayol $\mathrm{F}$ at 2 day-intervals as indicated. Upper curve: Mean body weight of mice, with standard deviation. Lower curve: Survival curve of mice.

most effective: Without adjuvant, cord factor-MBSA complex was entirely ineffective even by the same routes. Intravenous vaccination without adjuvant was less effective. Either cord factor or MBSA alone was entirely ineffective. When mycolic acid or acetylated cord factor was substituted for cord factor and BSA for MBSA, neither the formation of a lipid-protein complex nor the effective protection against tuberculous infection was seen. The protective potency of cord factor-MBSA complex was found in a number of experiment to be as potent as that of live BCG vaccine.

The effect of cord factor-MBSA complex to protect mice from living infection was found to be highly specific for the infection with M. tuberculosis. The experimental infection of mice with neither Listeria monocytogenes, Brucella abortus, Salmonella enteritidis nor Salmonella typhimurium was protected by the vaccination with cord factor-MBSA complex.

Summary: A method for preparing a complex of cord factor and methylated bovine serum albumin was developed. Chemical analysis of the formed 


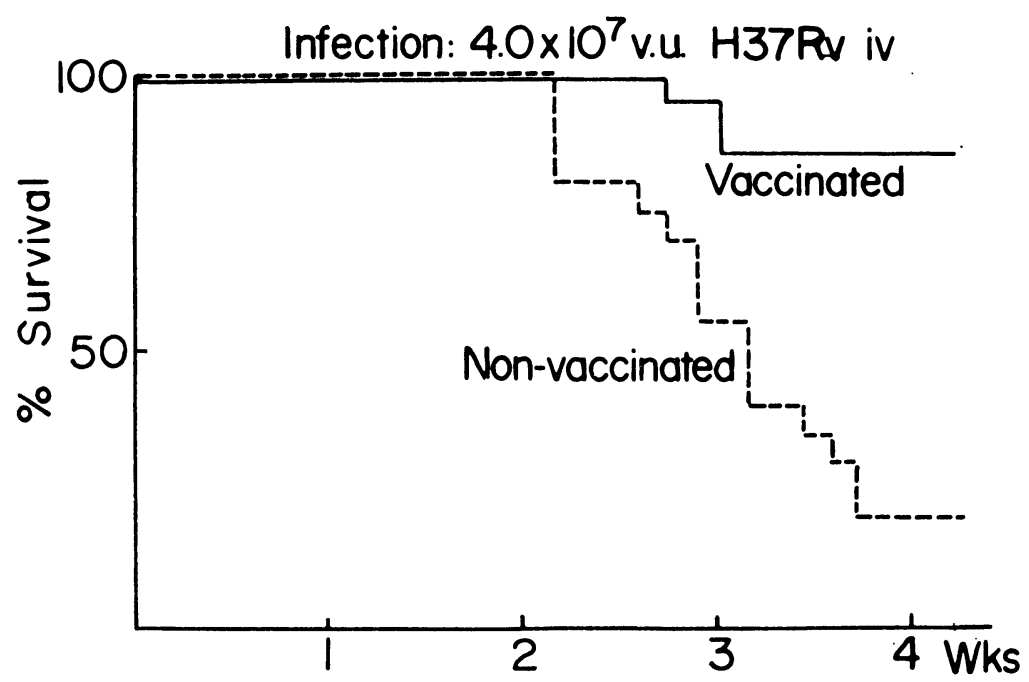

Fig. 2. Survival curve of mice infected with virulent $M$. tuberculosis H37Rv after the vaccination with cord factor-MBSA complex. Twenty mice vaccinated with cord factor-MBSA complex and twenty non-vaccinated control mice were infected intravenously with $4.0 \times 10^{7}$ viable cells of $\mathrm{H} 37 \mathrm{Rv}$.

complex revealed that the ratio of cord factor to MBSA in the complex was $10: 1$.

The vaccination with cord factor-MBSA complex protected mice against both the toxic action of cord factor and the infection with virulent tubercle bacilli. Bacterial multiplication in the organs of mice was markedly inhibited by the vaccination with cord factor-MBSA complex. The protecting effect of cord factor-MBSA complex was specific for the tuberculous infection among various experimental infections of mice with a number of cytopathogenic bacteria.

\section{REFERENCES}

BRAY, G. A. (1960): A simple efficient liquid scintillater for counting aqueous solution in a liquid scintillation counter. Anal. Biochem., 1, 279-285.

INOUE, K. AND NoJimA, S. (1967): Immunochemical studies of phospholipids. III. Production of antibody to cardiolipin. Biochim. Biophys. Acta, 144, 409-414.

KATO, M. (1966): Studies of a biochemical lesion in experimental tuberculosis in mice. IV. Effect of tubercle bacilli grown in vivo on respiratory chain enzymes. Am. Rev. Respirat. Disease, 94, 395-399.

KATO, M. (1967): Procedure for the preparation of aqueous suspension of cord factor. Am. Rev. Respirat. Disease, 96, 553.

KATO, M. (1968 a): Studies of a biochemical lesion in experimental tuberculosis in mice. VII. Structural and functional; damage in mouse liver mitochondria under the toxic action of cord factor. Am. Rev. Respirat. Disease, 98, 260-269.

Kato, M. (1968 b): Studies of a biochemical lesion in experimental tuberculosis in mice. VIII. Effect of derivatives and chemical analogues of cord factor on structure and function of mouse liver mitochondria. Am. Rev. Respirat. Disease, 98, 668-676. 
KATO, M. (1969): Studies of a biochemical lesion in experimental tuberculosis in mice. XI. Mitochondrial swelling induced by cord factor in vitro. Am. Rev. Respirat. Disease, $100,47-53$.

KATO, M. AND FuKUSHI, K. (1969): Studies of a biochemical lesion in experimental tuberculosis in mice. X. Mitochondrial swelling induced by cord factor in vivo accompanying biochemical change, Am. Rev. Respirat. Disease, 100, 42-46.

KATO, M. (1970): Site II specific inhibition of mitochondrial oxidative phosphorylation by trehalose-6,6'-dimycolate (cord factor) of Mycobacterium tuberculosis. Arch. Biochem. Biophys., 140, 379-390.

MANDEll, J. D. AND HeRShey, A. D. (1960): A fractionating column for analysis of nucleic acids. Anal. Biochem., 1, 66-77.

Noll, H., Bloch, H., Asselineau, J. ANd Lederer, E. (1956): The chemical structure of the cord factor of Mycobacterium tuberculosis. Biochim. Biophys. Acta, 20, 299-309.

REED, L. J., AND MUENCH, H. (1938): A simple method of estimating fifty per cent endpoints. Am. J. Hygiene, 27, 493-497.

\title{
PHAGE GENETIC ANALYSIS OF THE MECHANISM OF SYNTHESIS OF DIPHTHERIAL TOXIN IN NONTOXINOGENIC CORY NEBACTERIUM DIPHTHERIAE DIRECTED BY NONLYSOGENIZING PHAGE
}

\author{
Morihiro MATSUDA, ChIE KANEI AND MASAhiKo YONEDA \\ Department of Tuberculosis Research I, Research Institute \\ for Medical Diseases, Osaka University, Osaka
}

Toxinogeny in Corynebacterium diphtheriae has been known to be determined by specific corynebacteriophage (Freeman, 1951; Groman, 1955; Barksdale, 1955). However until now little has been clarified on the exact relationship between the genetic factor controlling toxin production and the genes in the phage genome.

We have recently established a lytic system (Matsuda and Barksdale, 1966, 1967; Matsuda, 1968) for investigating, phage-directed synthesis of diphtherial toxin, in which an obligately lytic, nonlysogenizing phage $\beta^{\text {hv }}$ tox ${ }^{+}$has been used to inject the toxinogenic factor into cells of a nontoxinogenic strain of Corynebacterium diphtheriae designated $\mathrm{C} 7 \mathrm{~s}(-)$ tox ${ }^{-}$.

Thus by employing this lytic system, in an attempt to elucidate the relationship between expression of the toxinogenic factor and expression of the genes in the phage genome which follows temporal sequence, we have first isolated temperature-sensitive mutants (ts mutants) of this phage, characterized them and examined effects of these mutations on the toxin production under the nonpermissive conditions.

Temperature-sensitive mutants of $\beta^{\text {hv }}$ phage which could produce progeny at $30 \mathrm{C}$ but not at $38 \mathrm{C}$ were isolated by treating the phage with $\mathrm{NaNO}_{2}$ or by growing the phage infected cells in the presence of 2-aminopurine or in the 
presence of $\mathrm{N}$-methyl- $\mathrm{N}$-nitrosoguanidine. In the last case, nitrosoguanidine treated phage were further adsorbed to the cells at the multiplicity of about one and the phage infected cells were subsequently incubated at $38 \mathrm{C}$ in the growth medium containing anti- $\beta^{\text {hv }}$ serum to select lysis negative mutants from the surviving infective centers. Complementation tests enabled us to classify the ts mutants thus obtained into ten groups. Mutations were mapped by performing two-factor crosses between pairwise combinations. These ts mutations were further characterized by (1) temperature-shift $(30 \mathrm{C}$ to $38 \mathrm{C}$ of the mutant phageinfected cells) experiments in terms of their ts steps in the intracellular growth of phage, by (2) examining electronmicroscopically phage lysates obtained under the nonpermissive conditions in cases of lysis $(+)$ mutants and by (3) examining whether DNA synthesis occurred under the nonpermissive conditions.

Effects of these mutations on the toxin production were then observed. It was found that toxin production occurred in nontoxinogenic diphtheria bacilli infected with "late mutants" or with "early mutants" of the phage. Thus diphtherial toxin production took place without phage lysis, formation of mature plaque-forming particles or even without synthesis of phage DNA.

The toxin synthesized under the direction of phage mutants was compared with the toxin produced by classic toxinogenic strain PW 8 of Corynebacterium diphtheriae by means of immunodiffusion and of polyacrylamide gel electrophoresis. No distinction has been so far observable between these toxins.

\section{REFERENCES}

FreEman, V. J. (1951): Studies on the virulence of bacteriophage infected strains of Coryrnebacterium diphtheriae. J. Bacteriol. 61, 675-688.

GROMAN, N. B. (1955): Evidence for the active role of bacteriophage in the conversion of nontoxinogenic Corynebacterium diphtheriae to toxin production. J. Bacteriol., 69, 9-15.

BARKSDALE, L. (1955): Sur quelques bactériophages de Corynebacterium diphtheriae et leurs hôtes. C. R. Acad. Sci., Paris 240, 1831-1833.

MATSUdA, M. AND BARKSDALE, L. (1966): Phage-directed synthesis of diphtherial toxin in nontoxinogenic Corynebacterium diphthriae. Nature, 210, 911-913.

MATSUDA, M. AND BARKSDALE, L. (1967): System for the investigation of the bacteriophage-directed synthesis of diphtherial toxin. J. Bacteriol., 93, 722-730.

MatsudA, M. (1968): Relationship between phage and toxin prodution. Proteins, Nucleic Acids and Enzymes, 13, 988-998. (text in Japanese). 


\title{
PHAGE-CONVERSION OF TOXIGENICITY IN CLOSTRIDIUM BOTULINUM TYPES C AND D
}

\author{
KATSUHIRO INOUE AND HIROO IIDA \\ Hokkaido Institute of Public Health, Sapporo, Hokkaido, Japan
}

A considerable amount of information has been obtained on the genetic control by phage of the toxin production in Corynebacterium diphtheriae (Freeman, 1951; Groman, 1955; Barksdale, 1959; Matsuda and Barksdale, 1967) and of the synthesis of somatic antigens in some species of Salmonella (Uetake, Luria and Burrous, 1958, Losick and Robbins, 1967). As previously reported (Inoue and Iida, 1968), we could demonstrate bacteriophages in six types of C. botulinum and the present paper deals with the role of some of these phages (types $\mathrm{C}$ and D) in the toxin production by those organisms.

\section{Materials AND MethodS}

The following six strains of $C$. botulinum were used. (1) C. botulinum type C, strain Stockholm (+) Tox ${ }^{+}$and (2) C. botulinum type D, strain $1873(+)$ Tox ${ }^{+}$; these two strains are stable toxin producers stored in our laboratory. (3) Strain AO-2 (-) Tox ${ }^{-}$and (4) Strain N-71 (+) Tox ${ }^{-}$; these two strains are derived from type C, strain Stockholm. (5) Strain $151(-)$ Tox $^{-}$and (6) Strain 139 (-) Tox ${ }^{-}$; these two strains are derived from type D, strain 1873.

The following four lines of phages were used. (1) st Tox ${ }^{+}$, (2) st-1 Tox ${ }^{-}$, (3) $\mathrm{d}^{\mathrm{Tox}}{ }^{+}$and (4) d-1 Tox ${ }^{-}$. These phages were obtained through induction by Mitomycin $\mathrm{C}$ of the parent lysogenic strains. The induced lysates were added to young cells of sensitive indicator strains and the lytic lysate was obtained. After serial 15 passages, each lytic lysate was filtered through Millipore filter HA (pore size: $0.45 \mathrm{~m} \mu$ ). It was found that at least $10^{7}-10^{8}$ phage particles per $\mathrm{ml}$ were contained in these lytic lysates by the lytic test in test tubes. Plaque formation by these phages has not yet been successful because of the difficulty in obtaining homogeneous bacterial lawn on agar plates in $C$. botulinum types $\mathrm{C}$ and $\mathrm{D}$.

As reported in the previous paper (Inoue and lida, 1970), TYG broth and cooked meat broth were used for preparation of phage lysates and for toxicity test, respectively. Immune sera against types $C$ and $D$ phages were prepared by immunizing rabbits with the lytic lysates of strain $\mathrm{N}-71$ which contained phage st-1 Tox $^{-}$and of strain 139 which contained phage d-1 Tox ${ }^{-}$, respectively. Antitoxic sera for types $\mathrm{C}$ and $\mathrm{D}$ toxins were prepared and distributed by courtesy of the National Communicable Disease Center, Atlanta, U. S. A.

\section{RESULTS}

I. Isolation of non-lysogenic and non-toxigenic mutants

A few drops of cultures of two parent strains (type C, strain Stockholm and type D, strain 1873) were each added to TYG broth which contained acridine 
orange in amounts of $25-50 \mu \mathrm{g} / \mathrm{ml}$. After being kept at $37 \mathrm{C}$ for $18 \mathrm{hr}$, the cultures were streaked on blood agar plates and incubated anaerobically at $37 \mathrm{C}$ for $48 \mathrm{hr}$. Colonies were picked up and inoculated into cooked meat broth. The tubes were incubated at $37 \mathrm{C}$ for $2-3$ days and tested their toxicity by intraperitoneal injection into mice.

Of 188 colonies from type C, strain Stockholm, 8 were found to be nontoxigenic and of 190 colonies from type D, strain 1873,8 were also found to be non-toxigenic. These non-toxigenic mutants were found to be non-lysogenic by the lytic test with induced lysates from parent strains. This suggested that there is a close relationship between toxigenicity and lysogenicity in C. botulinum types $\mathrm{C}$ and $\mathrm{D}$. Later a mutant $(\mathrm{N}-71)$ which is lysogenic but not toxigenic was isolated from type C, strain Stockholm, by the treatment with N-methyl-N'nitrosoguanidine.

II. Conversion to toxigenicity from non-toxigenicity by lysates from toxic cultures

Non-lysogenic and non-toxigenic mutants, strain AO-2 and strain 151, were each treated by induced lysates from toxigenic parent strains, Stockholm and 1873. Thus each $0.5 \mathrm{ml}$ of young sensitive cell culture and the lysate were mixed in a test tube to which $2 \mathrm{ml}$ of fresh TYG broth was added. The mixtures were kept at $37 \mathrm{C}$ for $6 \mathrm{hr}$. Then a few drops of each mixture were streaked onto blood agar plates, incubated anaerobically at $37 \mathrm{C}$ for $48 \mathrm{hr}$, picked up each 50 colonies at random and inoculated them into cooked meat tubes. These tubes were incubated at $37 \mathrm{C}$ for 2-3 days and tested the toxicity of the supernatants by injection into mice. Also the lytic test was carried out on each culture.

As shown in Table $1,96 \%$ and $88 \%$ of the surviving cells were lysogenized and became toxigenic in strains $\mathrm{AO}-2$ and 151 , respectively. The remaining cells were found to be non-toxigenic and showed a marked lysis after mixing with respective lysates. The lysogenic and toxigenic characters of these converted cultures were found to be stable after several passages in cooked meat broth.

Of particular interest is the result obtained with strain 139 which derived from type $\mathrm{D}$, strain 1873 , by treating with acridine orange. This non-toxigenic mutant was not converted to toxigenic by induced lysate from type D, strain 1873, but converted to toxigenic by induced lysate from type C, strain Stockholm. As shown in Table 1, the toxin produced by this converted culture was found to be of type $\mathrm{C}$ by toxin-antitoxin neutralization test.

III. Characteristics of converting agents

To obtain evidences supporting that the conversion is due to phage, several experiments were carried out with strain AO-2 and type $\mathrm{C}$ lysate obtained from strain Stockholm. The results are summarized in Table 2.

As shown in Table 2, treatment of the lysate by trypsin or DNAase did not destroy the converting ability of the lysate. Antiserum prepared for the lysate obtained from strain N-71 was found to neutralize the converting ability of the lysate from strain Stockholm at a dilution of $1: 60$. Also the filtrate of the lysate obtained through Gelman filter (pore size: $0.05 \mathrm{~m} \mu$ ) did not show any converting ability as expected from the large size (head diameter: $0.12 \mathrm{~m} \mu$ ) of 
Table 1. Test for Converting Ability of Phages Obtained from Lysogenic Strains of C. botulinum types $\mathrm{C}$ and D

\begin{tabular}{cccccc}
\hline $\begin{array}{c}\text { Indicator } \\
\text { strain }\end{array}$ & Phage & $\begin{array}{c}\text { No. of colonies } \\
\text { tested }\end{array}$ & $\begin{array}{c}\text { No. of colonies } \\
\text { converted }\end{array}$ & Percent & $\begin{array}{c}\text { Toxin } \\
\text { produced }\end{array}$ \\
\hline \multirow{3}{*}{ Type C } & st & 50 & 48 & 96 & C \\
AO-2 & st-1 & 50 & 0 & 0 & \\
& d & 50 & 0 & 0 & \\
\hline & d-1 & 50 & 0 & 0 & \\
Type D & st & 50 & 0 & 0 & \\
151 & st-1 & 50 & 0 & 0 & D \\
& d & 50 & 44 & 88 & \\
& d-1 & 50 & 0 & 0 & C \\
Type D & st & 80 & 75 & 94 & \\
139 & st-1 & 50 & 0 & 0 & \\
& d & 50 & 0 & 0 & \\
\hline
\end{tabular}

Table 2. Effects of Various Treatments upon Converting Ability of st-Phage

\begin{tabular}{lccc}
\hline Treatment & $\begin{array}{c}\text { No. of colonies } \\
\text { tested }\end{array}$ & $\begin{array}{c}\text { No. of colonies } \\
\text { converted }\end{array}$ & $\begin{array}{c}\text { Percent } \\
\text { conversion }\end{array}$ \\
\hline Control & 20 & 20 & 100 \\
Trypsin $^{1}$ & 20 & 18 & 90 \\
DNAase $^{2}$ & 20 & 20 & 100 \\
Anti-serum $^{3}$ & 20 & 0 & 0 \\
Filtration $^{4}$ & 20 & 0 & 0 \\
Heat $^{5}$ & 20 & 0 & 0 \\
\hline
\end{tabular}

1. Trypsin (EC 3. 4. 4. 4.) Sigma chemical co., $100 \mu \mathrm{g} / \mathrm{ml}, \mathrm{pH} 8.2,37 \mathrm{C}$ for $2 \mathrm{hr}$.

2. DNAase (EC 3.1.4.5) Worthington biochemical co., $20 \mu \mathrm{g} / \mathrm{ml}, \mathrm{pH} 7.2,37 \mathrm{C}$ for $2 \mathrm{hr}$.

3. Anti-st 1-phage serum was added to phage suspension at final concentration of 1:60. The reaction mixture was kept at room temperature for $3 \mathrm{hr}$.

4. Phage suspension was filtered through Gelman Filter GA-10 (pore size: 0.05 $\mathrm{m} \mu)$.

5. Heated at $60 \mathrm{C}$ for $30 \mathrm{~min}$.

the phage concerned. Heat-treatment at $60 \mathrm{C}$ for $30 \mathrm{~min}$ destroyed the converting ability of the lysate, but not at $55 \mathrm{C}$ for $30 \mathrm{~min}$.

Similar results were obtained with $C$. botulinum type D where strain 151 and the lysate from strain 1873 were used except that the lysate lost its converting ability after being heated at $55 \mathrm{C}$ for $30 \mathrm{~min}$.

All of the above mentioned experimental results strongly suggest the possibility that the conversion is carried out by phages contained in the lysates from parent strains. The high percentages in conversion suggest that the phenomenon is not transduction but phage-conversion. 
IV. Demonstration of different phages in induced lysates

Because of the difficulty in obtaining a homogeneous bacterial lawn on agar media in $C$. botulinum types $\mathrm{C}$ and $\mathrm{D}$, no attempt has been successful in plaque formation by these phages. However, we have had some evidences for the existence of different phages in the induced lysates used in the present experiments.

As for type $\mathrm{C}$, at least two different phages were obtained. The first one, phage st $\mathrm{Tox}^{+}$, was obtained from the induced lysate of strain Stockholm by serial passages through strain AO-2. The second phage, st-1 Tox ${ }^{-}$, was obtained from the induced lysate of strain N-71 (a lysogenic but non-toxigenic mutant) by serial passages through strain AO-2. It is not known whether phage st-1 Tox ${ }^{-}$ is present in the parent strain Stockholm or a mutant phage of st Tox ${ }^{+}$.

As for type D, at least two different phages were also obtained. The first

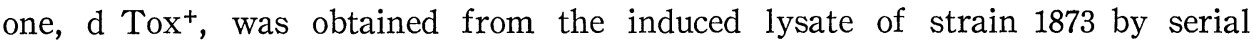
passages through strain 151 . The second one, d-1 Tox ${ }^{-}$, was obtained from the induced lysate of strain 1873 by serial passages through strain 139 . This suggests the existance of at least two different phages in the induced lysate of the parent strain 1873.

\section{REFERENCES}

BARKSDALE, L. (1959): Lysogenic conversions in bacteria. Bacteriol. Rev., 23, 202-212.

FreEMAN, V. J. (1951): Studies on the virulence of bacteriophage-infected strains of Corynebacterium diphtheriae. J. Bacteriol., 61, 675-688.

GROMAN, N. B. (1955): Evidence for the active role of bacteriophage in the conversion of nontoxigenic Corynebacterium diphtheriae to toxin production. J. Bacteriol., 69, 9-15.

INOUE, K. AND IIDA, H. (1968): Bacteriophages of Clostridium botulinum. J. Virol., 2, 537-540.

INOUE, K. AND IIDA, H. (1970): Conversion of toxigenicity in Clostridium botulinum type C. Japan. J. Microbiol., 14, 87-89.

Losick, R. AND RoBBins, P. W. (1967): Mechanism of $\varepsilon^{15}$ conversion studied with a bacterial mutant. J. Mol. Biol., 30, 445-455.

MATSUDA, M. AND BARKSDALE, L. (1967): System for the investigation of the bacteriophage-directed synthesis of diphtherial toxin. J. Bacteriol., 93, 722-730.

Uetake, H., Luria, S. E. AND Burrous, J. W. (1958): Conversion of somatic antigens in Salmonella by phage infection leading to lysis or lysogeny. Virology, 5, 68-91. 


\title{
A TOXIC PROTEIN FROM INSECT PATHOGEN BACILLUS THURINGIENSIS
}

\author{
SATORU AKUNE*, TADAO WATANABE**, JUN-ICHIRO MUKAI*, \\ RYOKI TSUTSUI* AND KAZUNORI ABE*** \\ *Department of Agricultural Chemistry and **Department of Food Science \\ and Technology, Faculty of Agriculture, Kyushu University and \\ ***Fukuoka Women's Junior College, Fukuoka, Japan
}

In recent years, research on insecticides for pest control has made a remarkable progress and contributed greatly to the advancement of agricultural production. These chemical insecticides are usually nonspecific, are effective on not only harmful insects, but also their natural enemies and many other useful animals. Consequently, they have influenced the ecological balance of the living things on the earth.

As a measure to make up for the defect of the chemical insecticides, a microbial control using insect-pathogenic bacteria is being paid attention. In 1901, a species of pathogenic bacteria was discovered by Ishiwata (1901) in the infected silkworm larvae, and was called by him "Sotto Bacillen". The organism was later named Bacillus thuringiensis. In European and North American countries, this and some related species are cultured in large quantities in the factories and actually sprayed over fields and forests for pest control. In Japan, however, the practical use of such bacteria has long been prohibited in fear of the possible effect on silkworm rearing, and the fundamental study on this subject has scarcely been made. We are primarily interested in the fact that this bacterium produces a crystal inclusion which is responsible for the selective toxicity for many Lepidopterous and some other insects, and have been studying the chemical structure of this toxic substance and its mode of action on these insects (Watanabe et al., $1966 \mathrm{a}, 1966 \mathrm{~b}, 1967 \mathrm{a}, 1967 \mathrm{~b}, 1967 \mathrm{c}$ ). It should also be noted that the crystal inclusion is composed of regular, self-assembly units, and that the process of assemblage is an interesting problem pertaining to the polymerization of protein in the living organisms.

Bacillus thuringiensis strain T 84 A-1 (Aizawa and Fujiyoshi, 1964) of crystalliferous bacteria was used throughout the experiments. The bacteria were cultured in nutrient broth. After autolysis, the crystal inclusion was separated from cell debris and spores by chloroform treatment and centrifugation. The crystal inclusion obtained in this way was diamond-shaped octahedra, and regular ridges were observed on the surface. The toxicity of the inclusion was lost by heating, strong acidity or alkalinity, in particular above $\mathrm{pH}$ 10.5. The toxin was insoluble at $\mathrm{pH}$ below 7.0. The toxin contained $17.1 \%$ nitrogen, $0.5 \%$ amino sugar, and no phosphorus. Absorption maximum and minimum were at 278 and $250 \mathrm{~m} \mu$, respectively. $\mathrm{E}_{1 \mathrm{~cm}}^{1 \%}=12.88$ at $280 \mathrm{~m} \mu$ in $0.1 \mathrm{~N} \mathrm{NaOH}$. Formerly the crystal inclusion was solubilized by alkali above $\mathrm{pH} 12$, for example $0.05 \mathrm{~N}$ $\mathrm{NaOH}$ or by treating with a digestive protease of the Lepidopterous insects 
Table 1. Physicochemical properties of toxin

\begin{tabular}{lllllll}
\hline & $\mathrm{S}_{20, \mathrm{w}}^{0}$ & $\mathrm{D}_{20, \mathrm{w}}^{0}$ & {$[\mu]$} & $\mathrm{f} / \mathrm{f}_{0}$ & $* \mathrm{P}$ & $\mathrm{M} . \mathrm{W}$. \\
\hline $\begin{array}{l}\text { 8.0 M Urea } \\
\begin{array}{l}5 \% \text { s-amino-n- } \\
\text { caproic acid in }\end{array}\end{array}$ & 12.45 & 1.70 & 4.47 & 2.1 & 24 & 708,000 \\
$\begin{array}{l}1.0 \mathrm{M} \text { glycine } \\
0.05 \mathrm{M} \text { SDS }\end{array}$ & 9.65 & $2.5\left(\mathrm{D}_{20, \mathrm{w}}^{0.32}\right)$ & - & 1.8 & 14 & 373,000 \\
& 1.98 & 6.34 & 3.27 & 1.8 & 14 & 25,000 \\
\hline
\end{tabular}

*These values were calculated assuming that protein molecule was not hydrated.

(Angus, 1956; Lecadet et al., $1967 \mathrm{a}, 1967 \mathrm{~b}$ ). These drastic or enzymic procedures, however, inevitably brought about denaturation or partial proteolysis of the toxic protein, and seemed unfavourable. We have now observed that the toxic protein could be dissociated and associated reversibly by employing appropriate conditions of $\mathrm{pH}$, temperature, reducing agents, or solvents. The crystal, when treated with $0.1 \mathrm{M}$ dithiothreitol in $0.2 \mathrm{M}$ glycine- $\mathrm{NaOH}$ buffer, $\mathrm{pH}$ 10.0 in the cold, showed a homogeneous ultracentrifugal pattern. Among various

Table 2. Amino acid composition of toxin

\begin{tabular}{lrr}
\hline & \multicolumn{2}{c}{ Number of residue a) } \\
\cline { 2 - 3 } & Calculation & Integration $\mathrm{h})$ \\
\hline Aspartic acid & $30.0 \mathrm{~b})$ & 30 \\
Threonine & $12.1 \mathrm{c})$ & 12 \\
Serine & $15.3 \mathrm{c})$ & 15 \\
Glutamic acid & $28.3 \mathrm{~d})$ & 28 \\
Proline & $9.4 \mathrm{~d})$ & 9 \\
Glycine & $14.6 \mathrm{~d})$ & 15 \\
Alanine & $11.6 \mathrm{~d})$ & 12 \\
Half-Cystine & $3.9 \mathrm{e})$ & 4 \\
Valine & $13.3 \mathrm{~d})$ & 13 \\
Methionine & $2.0 \mathrm{c})$ & 2 \\
Isoleucine & $11.8 \mathrm{f})$ & 12 \\
Leucine & $18.0 \mathrm{f})$ & 18 \\
Tyrosine & $9.0 \mathrm{~d})$ & 8 \\
Phenylalanine & $9.7 \mathrm{~d})$ & 10 \\
Lysine & $5.3 \mathrm{~d})$ & 5 \\
Histidine & $3.7 \mathrm{~d})$ & 4 \\
Arginine & $14.8 \mathrm{c})$ & 15 \\
Tryptophan & $3.1 \mathrm{~g})$ & 3 \\
Total & 215.9 & 215 \\
\hline
\end{tabular}
a) Based on a molecular weight of 25,000
b) Assumed to give definite value independent of time of hydrolysis
c) Extrapolated value to zero time of hydrolysis
d) Average value from 24,48 and 78 hours hydrolysates
e) Estimation of sulfhydryl groups by DTNB
f) Maximum value adopted
g) Calculated from ultraviolet absorption method
h) Molecular weight calculated from this integral number of residues was 25,073.76 
kinds of solvents tested, glycine and $\varepsilon$-aminocaproic acid were found to prevent the association of the toxic protein solubilized by dithiothreitol. $8 \mathrm{M}$ urea was found to be ineffective in the dissociation of alkylated toxin, while $0.05 \mathrm{M}$ sodium dodecylsulfate (SDS) exhibited a marked dissociation effect. In $1 \mathrm{M}$ acetic acid after treatment with $8 \mathrm{M}$ urea or at $\mathrm{pH} 12$, the alkylated toxic protein was mostly in the associated form, giving in part small fragments of $1 \sim 2 \mathrm{~S}$ as seen in analytical ultracentrifugation. Table 1 summarizes the physicochemical data on the toxin under various conditions. Any condition tested gave a single sedimentation pattern. Table 2 gives amino acid composition of the toxin. The molecular weight (MW) of toxin in $8 \mathrm{M}$ urea was 708,000 . That in $0.05 \mathrm{M}$ SDS was 25,000 . The toxin, in $0.05 \mathrm{M}$ SDS, gave a single band on disc electrophoresis. This SDS-dissociated protein could associate reversibly on removal of SDS by dialysis. It is now under study to find whether this single band corresponds to the real subunit of the toxin or not. At the present moment, it seems that this subunit is a polypeptide of MW ca. 25,000, a number of this unit may be assembled into a protomer of MW ca. 373,000, which in turn may further develop into a dimer to give MW ca. 708,000. The binding force exerted between the protein units appears to be the electrostatic one, not the disulfide or metal-coordinated ones.

\section{REFERENCES}

Aizawa, K. AND Fujryoshi, N. (1964): The growth of Bacillus thuringiensis in dead larvae of the silkworm, Bombyx mori. J. Sericult. Sci. Japan, 33, 399-402.

ANGUS, T. (1956): Extraction, purification, and properties of Bacillus sotto toxin. Can. J. Microbiol., 2, 416-426.

IsHIDA, S. (1901): On a kind of a severe softnening disease (a swoon disease). Bull. Japan. Assoc. Raw Silk, 9, 1-5 (text in Japanese).

LECAdeT, M. M. AND Dedonder, R. (1967a): Enzymatic hydrolysis of the crystals of Bacillus thuringiensis by the proteases of Pieris brassicae. 1. Preparation and fractionation of the lysates. J. Invertebrate Pathol., 9, 301-321.

LECAdeT, M. M. AND MARTOURET, D. (1967 b): Enzymatic hydrolysis of the crystals of Bacillus thuringiensis by the proteases of Pieris brassicae. 2. Toxicity of the different fractions of the hydrolysate for larvae of Pieris brassicae. J. Invertebrate Pathol., 9, 322-330.

Watanabe, T., Tsutsui, R. And Iwahana, H. (1966a): Toxic crystals produced by Bacillus thuringiensis var. sotto. 1. Separation and Properties of crude toxin. J. Sericult. Sci. Japan., 35, 424-426.

Watanabe, T., Tsutsui, R. AND Iwahana, H. (1966 b): Toxic crystals produced by Bacillus thuringiensis var. sotto. 2. Sedimentation, diffusion, electrophoresis and fractionation by column chromatography of crude toxin. J.Sericult. Sci. Japan, 36, 424-426.

WatAnABE, T., IwAhANA, H., OGI, H. AND Tsutsui, R. (1967 a): Toxic crystals produced by Bacillus thuringiensis T 84 A-1. 1. Separation and properties of crude toxin. J. Sericult. Sci. Japan, 36, 11-15.

Watanabe, T., Iwahana, H., OGI, H. And Tsutsui, R. (1967 b): Toxic crystals produced by Bacillus thuringiensis T 84 A-1. 2. Action of gut juice of silkworm larvae for toxic crystals. J. Sericult. Sci. Japan, 36, 16-22.

Watanabe, T., Tsutsui, R., Iwahana, H. And ABE, K. (1967 c): Chemistry of the toxic crystals produced by Bacillus thuringiensis. Proc. Joint U. S. Japan Seminar on microbial control of insect pests, Fukuoka, 21-23. 


\title{
MECHANISM OF HYPERSENSITIVITY TO HISTAMINE OF RATS TREATED WITH BORDETELLA PERTUSSIS VACCINE
}

\author{
Tokuro FUKUDA, NAmiYo HATA AND Setsuko AKIYAMA \\ Department of Physiology, Chiba University School of Medicine, \\ Chiba 280, Japan
}

Since Parfentjev and Goodline (1948) reported that the injection of Bordetella pertussis vaccine renders mice highly sensitive to the lethal effects of histamine, evidence has been accumulated to show that vaccinated rats and mice are not only sensitive to histamine and serotonin, but also susceptible to other stresses, just as the case with adrenalectomized animals (Kind, 1958). However, the underlying mechanisms have been variously interpreted and as yet remain unsettled. Therefore, we intended to examine the lethal mechanism of histamine intoxication in pertussis-inoculated rats.

\section{Materials and Methods}

Rats of the Wistar strain of both sexes weighing about $150 \mathrm{~g}$ were used. For blood pressure determinations, animals weighing more than $200 \mathrm{~g}$ were used. Experiments were made during the period of maximum sensitization to histamine, i. e. 4-6 days following an intraperitoneal injection of $B$. pertussis vaccine $(0.2 \mathrm{ml}$ containing $2 \times 10^{10}$ organisms). Histamine in $10 \mathrm{mg} / \mathrm{kg}$ was injected into the tail vein over a period of 15 seconds. The calcium contents were determined flamephotometrically after Geyer and Bowie (1961). Ultrafiltration methods were after Toribara et al. (1957).

\section{Results and Discussion}

A histamine dose of $50 \mathrm{mg} / \mathrm{kg}$ given intravenously was $100 \%$ lethal to vaccinated rats. The $\mathrm{LD}_{100}$ of histamine in adrenalectomized rats was $100 \mathrm{mg} / \mathrm{kg}$. The vaccinated group was more sensitive to histamine than the adrenalectomized group. Moreover, pertussis vaccine sensitized animals even in the absence of the adrenals.

The threshold dose of histamine inducing a blood pressure fall was $1-5 \mu \mathrm{g} / \mathrm{kg}$ in adrenalectomized rats, pertussis-vaccinated rats and also in the normal rats. The increased sensitivity to the lethal effect of histamine, thus, seems not to be due to an increased sensitivity to the immediate hypotensive effect of histamine. With a histamine dose of $10 \mathrm{mg} / \mathrm{kg}$ given intravenously, an immediate rapid drop in blood pressure occurred in all cases. A slow recovery from the initial drop ensued in normal rats and in adrenalectomized rats pretreated with cortisone. In pertussis-inoculated or adrenalectomized rats a progressive hypotension followed. In the pertussis-vaccinated group, often a sudden fall of blood pressure occurred reaching to the zero line within several minutes after the injection associating with cardiac irregularities. 


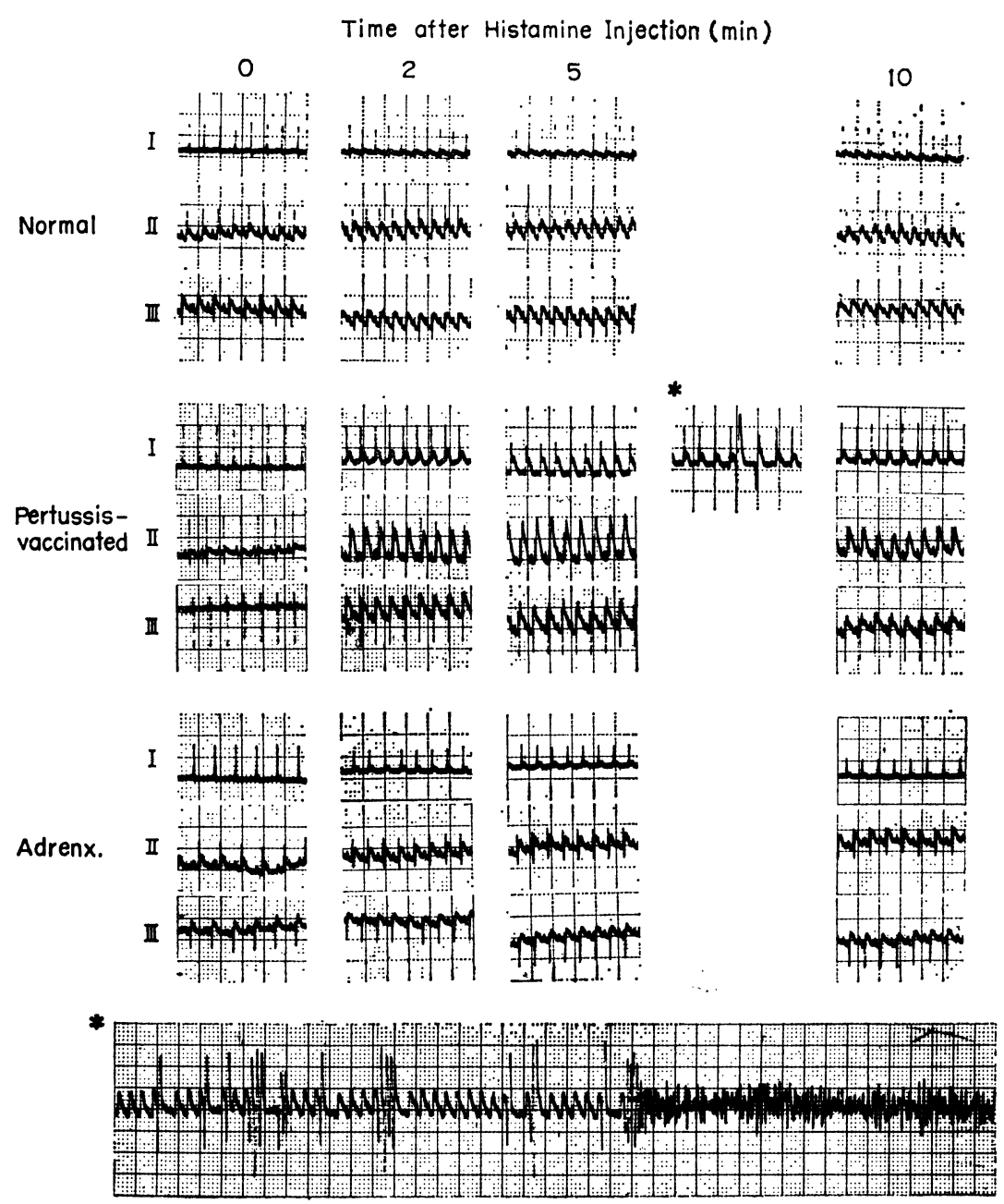

Fig. 1. ECG changes after intravenous histamine injection $(10 \mathrm{mg} / \mathrm{kg})$. At the mark*, often lethal cardiac irregularities appeared as shown at the bottom of the figure. On anesthetized animals.

As shown in Fig. 1, an enlargement of the T wave in the ECG was extremely prominent in pertussis-inoculated rats and cardiac irregularities of various forms began to appear within several minutes. Of 17 cases, ventricular extrasystole appeared in $53 \%$ and ventricular flutter in $12 \%$ of the cases. The cardiac irregularities occurred even in glucocorticoid-pretreated vaccinated rats. This was in contrast to the resustinating effect of the corticoid in the adrenalectomized animals.

Hyperkalemia was prominent in the pertussis-vaccinated and the adrenalectomized groups, but, contrary to the inference of Bovet et al. (1958), this does not seem to be related to the appearance of the cardiac irregularities observed in the pertussis-vaccinated group. Since at the time of the onset of the cardiac 


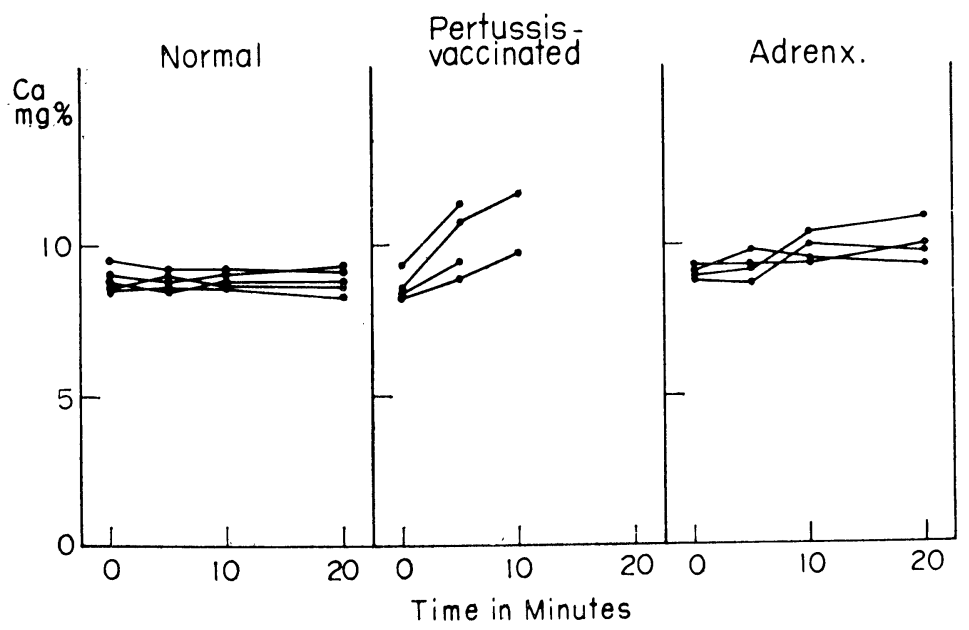

Fig. 2. Changes in serum calcium level after intravenous histamine injection $(10 \mathrm{mg} / \mathrm{kg})$. On anesthetized animals.

irregularities the rise in the serum potassium level was immature and no cardiac irregularities appeared in the adrenalectomized group despite a marked rise in the serum potassium level.

The progressive enlargement of the $\mathrm{T}$ wave was similar to that usually observed in a mildly hypercalcemic state induced by an intraperitoneal injection of an isotonic $\mathrm{CaCl}_{2}$ solution. Changes in the total serum calcium level after the histamine injection were therefore examined not only in pertussis-vaccinated rats, but also in normal and adrenalectomized rats. The results are illustrated in Fig. 2. An immediate and marked rise of the calcium level appeared in the vaccinated rats. From the vaccinated rats surviving till $10 \mathrm{~min}$ after the histamine injection, blood samples were obtained by cardiac puncture in an amount sufficient for determinations of the total and ultrafiltrable serum calcium concentrations. The total calcium concentration increased from 10.1 to 12.6 , also the ultrafiltrable calcium concentration markedly rose from 6.5 to 9.5. A similar tendency could also be noticed in adrenalectomized rats but was far less significant. The rise in the total calcium concentration induced by histamine injection was most prominent 4 days after pertussis vaccination.

An intraperitoneal injection of a $\mathrm{CaCl}_{2}$ solution $(1.2 \%, 2 \mathrm{ml} / 100 \mathrm{~g} \mathrm{b.} \mathrm{w.)}$ induced in normal rats mild hypercalcemia which reached $16.2 \mathrm{mg} \%$. When histamine was injected in these animals, the enlargement of the $\mathrm{T}$ wave was more marked and cardiac irregularities of various forms appeared within several minutes. Of 30 cases injected with $\mathrm{CaCl}_{2}$ and histamine, ventricular extrasystole appeared in $60 \%$ and ventricular flutter in $20 \%$ of the cases. Such incidences were almost comparable to that observed in the vaccinated rats injected with histamine.

If the appearance of hypercalcemia after the histamine injection in the vaccinated rats is due to the release of tissue calcium, then the affection of histamine would concern only with those tissues where rapid calcium exchange 
mechanisms exist. In an attempt to clarify this presumption, the calcium contents of the skin, lung, heart, liver and kidney 10 min after histamine injection were determined to compare with the control values in vaccinated rats. An appreciable reduction of the calcium content was confirmed in the kidney and the liver in the vaccinated rats, but not in normal rats treated similarly. The pertussis vaccination may have some influence upon the tissue calcium metabolism since the calcium contents of the liver and heart were higher in the vaccinated rats than in normal rats. The rise in the calcium content of the heart was most prominent 4 days after pertussis vaccination and showed dose responses.

A $\beta$-adrenergic blocking agent, contrary to the inferrence of $\mathrm{Munoz}$ and Bergman (1968) on mice, sensitized little to histamine in rats. The marked enlargement of the $\mathrm{T}$ wave and grave cardiac irregularities did not appear.

\section{Summary}

The mechanisms of sensitization to the lethal effect of histamine in rats induced by Bordetella pertussis vaccine were studied and found to be different from that induced by adrenalectomy. In the vaccinated rats, an immediate and marked rise of the serum calcium level appeared, and the serious cardiac irregularities often occurred several minutes after histamine injection followed by death. The increase in serum calcium seemed to be mainly due to a liberation of calcium from the kidney and the liver. It was inferred that the hypercalcemia was responsible for the induction of grave cardiac irregularities which was the main cause of acute death after histamine injection in the vaccinated rats.

The authors express their sincere thanks to Dr. Sachio Ogata (Medical Research Institure, Tokyo University) for the kind supply of Bordetella pertussis vaccine.

\section{REFERENCES}

Bovet, D., Kohn, R., Marotta, M. And Silvestrini, B. (1958): Some effects of histamine in the normal and Haemophilus pertussis vaccinated rat. Brit. J. Pharmacol., 13, $74-83$.

GEYER, R. P. AND BOWIE, E. J. (1961): The direct microdetermination of tissue calcium by flame photometry. Analyt. Biochem., 2, 360-369.

KIND, L. S. (1958): The altered reactivity of mice after inoculation with Brodetella pertussis vaccine. Bacteriol. Rev., 22, 173-182.

MUNOZ, J. AND BERGMAN, R. K. (1968): Histamine-sensitizing factors from microbial agents, with special reference to Bordetella pertussis. Bacteriol. Rev., 32, 103-126.

ParfentJev, I. A. AND Goodline, M. A. (1948): Histamine shock in mice sensitized with Hemophilus vaccine. J. Pharmacol. Exptl. Therap., 92, 411-413.

TORIBARA, T. Y., TEREPKA, A. R. AND DEWEY, P. A. (1957): The ultrafiltrable calcium of human serum. I. Ultrafiltration methods and normal values. J. Clin. Invest., 36 , 738-748. 


\title{
BIOLOGICAL ACTIVITIES OF THE PROTEIN MOIETY OF PSEUDOMONAS AERUGINOSA ENDOTOXIN
}

\author{
Chiyoji ABE*, Yuzuru HOMMA* AND G. M. FUKUI** \\ *Institute of Medical Sciences, University of Tokyo, Minato-ku, Tokyo \\ and ${ }^{* *}$ Wallace Laboratories, U. S. A,
}

\section{MECHANISM OF THE ADJUVANT EFFECT OF SALMONELLA LIPOPOLYSACCHARIDE ON ANTIBODY RESPONSE AT CELLULAR LEVEL}

\author{
MASAyasu NAKANO, TADAKATSU SHIMAMURA \\ AND KAZUHISA SAITO \\ Department of Microbiology, Keio University School of Medicine, \\ Shinjuku-ku, Tokyo
}

It is well known that lipopolysaccharide (LPS) extracted from gram-negative bacteria enhances the antibody response of animals when injected with an antigen (Landy and Braun 1964, Munoz 1964). However, the mode of action of LPS on the host cell participating in antibody production and active molecule in LPS responsibly for its adjuvant effect still remain unsolved. The present study aims to solve these problems.

LPS was extracted from Salmonella typhimurium LT 2 or its heptoseless mutant SL 1102 (Nakano and Saito 1967) by Westphal's method (1952, 1954). GLF-DE2 LPS extracted with chloroform-methanol from a heptoseless mutant strain of $S$. minnesota was kindly provided by Dr. N. Kasai of Showa University. DK1 adult mice (Ushiba et al. 1962) were used throughout the experiments. In most cases, $20 \mu \mathrm{g}$ of LT2 LPS in $0.2 \mathrm{ml}$ saline was intraperitoneally injected into mice as an adjuvant. For antigenic stimulation $10^{8}$ of washed sheep red blood cells (sRBC) were intravenously injected to mice. Antibody response of the mice was assessed by the number of plaque forming cells ( $\mathrm{PFC}$ ) in the spleen obtained in a modified technique of localized hemolysis in agar (Jerne et al. 1963). Number of 7S PFC was estimated by the indirect technique using hyperimmune rabbit anti-mouse- $\boldsymbol{\gamma}$-globulin serum (Dresser and Wortis 1965, Sterzl and Riha 1965).

Adjuvant effect of LPS on the primary and secondary responses.

After a simultaneous injection with $\mathrm{SRBC}$ and LPS, kinetics of the primary antibody response of the mice was examined by determining $\mathrm{PFC}$ in the spleen over a 14-day period. The number of $\mathrm{PFC}$ at $24 \mathrm{hr}$ after the immunization was 
still within the level of background PFC, but thereafter the number of PFC in LPS-treated immune mice was markedly greater than that in LPS-untreated immune mice. However, the general profile of the response in LPS-treated immune mice was similar to that seen in the immune controls. To see the effect of LPS on the secondary antibody response, the mice primed with sRBC 14 days previously were again injected with $\mathrm{SRBC}$ and LPS, and the PFC in these mice was examined over a 7-day period. Some adjuvant effect of LPS on the secondary response could be observed in both direct and indirect $\mathrm{PFC}$, but it was obviously weaker than that on the primary response.

Adjuvant effect of LPS on the memory cells.

To examine whether LPS can stimulate the memory cells, the mice primed with sRBC and LPS 14 days or 42 days in advance were again injected with sRBC, and the number of PFC in these mice were assessed over a 7-day period. In comparison with controls which were primed with sRBC alone, these mice contained greater number of $\mathrm{PFC}$ in their spleens, suggesting the stimulant effect of LPS on the memory cells.

\section{Relation between timing of LPS injection and its adjuvant effect on the primary response.}

Simultaneous injection with sRBC and LPS resulted in the greatest antibody response in mice. The longer the interval between the $\mathrm{SRBC}$ injection and LPS injection was, the less the adjuvant effect of LPS developed. The injection of LPS at 5 or $1 \mathrm{hr}$ before the PFC assay did not affect the number of PFC. This finding indicates that LPS does not stimulate directly PFC for synthesis of hemolytic antibody and secretion of the synthesized antibody.

\section{Effect of LPS on mice initiating antibody formation.}

The mice immunized $48 \mathrm{hr}$ in advance were injected with LPS and $48 \mathrm{hr}$ later the number of PFC in their spleen was determined. Adjuvant action of LPS in these mice could not be seen. This finding may suggest that LPS have no capability to stimulate antibody forming precursor cells.

\section{Transfer of LPS-treated macrophages or splenic cells to normal mice.}

Peritoneal macrophages (MP) were collected from the peritoneal cavities of normal mice with heparin Hanks' solution and then incubated with sRBC and LPS in a Falcon plastic dish. One hr after the incubation, non-adherent cells, unphagocytized $\mathrm{sRBC}$ and free LPS were removed from the dish by repeated washings with Hanks' solution. The adherent MP were scraped off from the bottom of the dish to make suspension and the suspension was intravenously injected into normal mice. Normal spleen cell suspension was also incubated in a dish for $30 \mathrm{~min}$. Non-adherent cells were transferred into another dish and again incubated with LPS for $30 \mathrm{~min}$. Then the non-adherent splenic cells were collected and repeatedly washed by centrifugation with Hanks' solution to remove free LPS and the washed cells and SRBC were injected into normal mice. At 72 or $48 \mathrm{hr}$ after the transfer with MP or splenic cells thus prepared, the number of $\mathrm{PFC}$ in the spleen of the recipient mice was examined. As shown in Table 
Table 1. Effect of LPS on the activity of peritoneal macrophages (MP) or non-adherent splenic cells (SC) in immune response

\begin{tabular}{|c|c|}
\hline $\begin{array}{l}\text { Treatment of donor cells }+ \\
\text { Treatment of the recipients }\end{array}$ & $\begin{array}{l}\text { Avg. no. }{ }^{4)} \pm \text { S. E. of } \\
\text { PFC per } 10^{7} \text { spleen cells }\end{array}$ \\
\hline LPS-treated MP1) & $4.5 \pm 1.1^{5)}$ \\
\hline non-treated $\mathrm{MP}^{1}$ ) & $5.8 \pm 1.5$ \\
\hline non-treated $\mathrm{MP}^{1)}+\mathrm{LPS} 10 \gamma$ i.v. & $20.7 \pm 3.6$ \\
\hline LPS-treated $\mathrm{SC}^{2)}+\mathrm{sRBC}$ & $45.9 \pm 10.1^{6)}$ \\
\hline the last washings for LPS-treated $\mathrm{SC}^{3)}+\mathrm{sRBC}$ & $15.3 \pm 6.1$ \\
\hline non-treated $\mathrm{SC}^{2)}+\mathrm{sRBC}$ & $14.4 \pm 2.3$ \\
\hline$+\mathrm{sRBC}$ & $12.4 \pm 7.8$ \\
\hline
\end{tabular}

1) $2.6 \times 10^{7} \mathrm{MP}$ were incubated with $1.5 \times 10^{8} \mathrm{sRBC}$ in the presence or absence of $10 \gamma \mathrm{LPS}$ (total volume, $5.0 \mathrm{ml}$ ) for $1 \mathrm{hr}$. $2.7 \times 10^{6} \mathrm{MP}$ were transferred to normal mouse.

2) $5 \times 10^{8} \mathrm{SC}$ were incubated with or without $25 \gamma$ LPS (total volume $2.5 \mathrm{ml}$ ) for $30 \mathrm{~min}$. $1.2 \times 10^{8} \mathrm{SC}$ were transferred to normal mouse.

3) $0.5 \mathrm{ml}$ of the last washings for LPS-treated SC was intravenously injected to normal mouse.

4) 5 mice per group.

5) Assay at $72 \mathrm{hr}$ after transfer.

6) Assay at $48 \mathrm{hr}$ after immunization.

1, the mice transferred with LPS-treated MP did not show any stimulation of $\mathrm{PFC}$ response, but the number of $\mathrm{PFC}$ in spleen of the mice transferred with LPS-treated non-adherent splenic cells increased significantly in comparison with that of mice transferred with non-adherent splenic cells not treated with LPS. These results suggest that LPS may act on non-adherent immunocompetent cells rather than on macrophages.

Antagonistic effect of LPS on immune-suppression caused by anti-lymphocyte serum $(A L S)$, anti-sRBC serum (ASS) or cortisone.

Antibody response of immunized animals is greatly impaired by the administration of ALS, ASS or cortisone. The target of ALS and ASS in the suppresion of antibody response to $\mathrm{sRBC}$ is presumed to be antigen-reactive cells (Möller and Zukoski 1968, Feldmann and Diener 1970). Cortisone is also supposed to impair splenic cells which are not derived from the bonemarrow (Levine and Claman 1970). Effect of LPS on immune response of the animals treated with these immunosuppresive agents should be worth examining. As shown in Table 2, LPS had obvious capability to restore the impaired immune response of these animals. These results strongly suggest that LPS may act on antigen-reactive cells to elicit its adjuvant action.

\section{Adjuvant effect of LPS extracted from heptose-less mutants.}

LT2 LPS consists of a complex of long sequence of various polysaccharide components and lipid, while SL1102 LPS and GLF-DE2 LPS, both of which are extracted from heptose-less mutants, are composed of only KDO and lipid. The heptose-less LPS exerted the same extent of adjuvant effect as LT2 LPS did, despite polysaccharide components in the heptose-less LDS differ markedly from 
Table 2. Antagonistic effect of LPS on immune-suppression caused by anti-lymphocyte serum, anti-sRBC serum or cortisone

\begin{tabular}{lc}
\hline Treatment of spleen donors & $\begin{array}{c}\text { Avg. no.4) } \pm \text { S. E. of } \\
\text { PFC per } 10^{7} \text { spleen cells }\end{array}$ \\
\hline ALS $(0.5 \mathrm{ml})^{1)}+\mathrm{sRBC}$ & $0.1 \pm 0.1^{5)}$ \\
ALS $(0.5 \mathrm{ml})$, LPS +sRBC & $6.6 \pm 5.3$ \\
ALS $(0.1 \mathrm{ml})+\mathrm{sRBC}$ & $1.1 \pm 0.3$ \\
ALS $(0.1 \mathrm{ml})+\mathrm{sRBC}$ & $5.3 \pm 1.2$ \\
sRBC & $8.7 \pm 2.6$ \\
sRBC + LPS & $44.9 \pm 17.0$ \\
\hline ASS $(0.5 \mathrm{ml})^{2)}+\mathrm{sRBC}$ & $3.3 \pm 0.2^{6)}$ \\
ASS $(0.5 \mathrm{ml})$, LPS+sRBC & $59.7 \pm 34.2$ \\
sRBC & $33.0 \pm 4.7$ \\
sRBC + LPS & $212.2 \pm 29.5$ \\
\hline cortisone acetate ${ }^{3)}+\mathrm{sRBC}$ & $2.6 \pm 1.0^{7)}$ \\
cortisone acetate, LPS+sRBC & $29.5 \pm 6.8$ \\
sRBC & $11.9 \pm 5.7$ \\
sRBC + LPS & $83.5 \pm 29.3$ \\
\hline
\end{tabular}

1) I. p. $24 \mathrm{hrs}$ before immunization. Agglutinin titer, $2^{9}$.

2) I. p. $0.5 \mathrm{hr}$ before immunization. $7 \mathrm{~S}$ agglutinin titer, $2^{9}$.

3) $12.5 \mathrm{mg}$ i. p. 48 and $24 \mathrm{hrs}$ before immunization.

4) 5 mice per group.

5) Assay at $48 \mathrm{hrs}$ after immunization.

6) Assay at $52 \mathrm{hrs}$ after immunization.

7) Assay at $48 \mathrm{hrs}$ after immunization.

those in LT2 LPS. Injection of less than $0.5 \mu \mathrm{g}$ of these LPS was enough to induce an apparent increase of PFC in the spleen of mice. These heptoseless LPS also possessed the same capability to elevate the number of back-ground PFC in the spleen of unimmunized mice as LT2 LPS did. These results indicate that KDO-lipid component is the active molecules of LPS for its adjuvant action. Moreover, the injection of LT2 LPS to SL1102 endotoxin (LPS)-tolerant mice did not elicit any apparent adjuvant action on the immune response in these mice, suggesting that longer polysaccharide sequence in LT2 LPS are not responsible for the adjuvant action.

Relation between lethal toxicity and adjuvant action of LPS.

Toxicities $\left(\mathrm{LD}_{50}\right.$ to mice) and minimal dose required for adjuvant action were quantitatively studied on LT2 LPS and its detoxified LPS prepared by treating with alkali (Neter et al. 1956). Any dissociation of the adjuvant effect from the toxicity could not be found in the detoxified LPS.

In summary, adjuvant action of LPS on antibody response to sRBC in mice was studied at the cellular level. Injection of LPS caused a significant increase in $19 \mathrm{~S}$ and $7 \mathrm{~S} \mathrm{PFC}$ in mouse spleen after the primary and secondary antigenic stimulations, and appeared also to stimulate memory cells. LPS seemed not to act directly on either PFC, antibody forming precursor cells or macrophages. It would be supposed that LPS acts on antigen-reactive cells, because LPS acted on non-adherent splenic cells resulting in the stimulation of PFC and LPS also 
exerted antagonistic effect on the immune suppression caused by ALS, ASS and cortisone. Active molecules in LPS responsible for adjuvant effect appeared to be present in KDO-lipid complex. Dissociation of the adjuvant effect from the lethal toxicity could not be achieved by detoxification of LPS by alkali-treatment.

\section{REFERENCES}

DRESSER, D. W. AND WORTIS, H. H. (1965): Use of an antiglobulin serum to detect cells producing antibody with low haemolytic efficiency. Nature, 208, 859-861.

Feldmann, M. AND Diener, E. (1970): Antibody-mediated suppression of the immune response in vitro. I. Evidence for a central effect. J. Expt1. Med. 131, 247-274.

Jerne, N. K., Nordin, A. AND Henry, C. (1963): The agar plaque technique for recognizing antibody-producing cells. p. 109-122. In Amos, B., and Koprowski, H. (eds.), Cell-bound antibodies. Wister Inst. Press.

LANDY, M. AND BRAUN, W. (1964): Bacterial endotoxins. Rutgers Univ. Press.

Levine, M, A. And Claman, H. N. (1970): Bone marrow and spleen: Dissociation of immunologic properties by cortisone. Science 167, 1515-1517.

MÖlleR, G. AND ZUKOsKI, C. (1968): Differential effect of heterologous anti-lymphocyte serum on antibody-producing cells and antigen-sensitive cells. J. Immunol. 101, 325-332.

MunOz, J. (1964): Effect of bacteria and bacterial products on antibody response. Advances Immunol. 4, 397-440.

NAKANO, M. AND SAITO, K. (1969): Chemical components in the cell wall of Salmonella typhimurium affecting its virulence and immunogenicity in mice. Nature, 222, 1085-1086.

Neter, E., Westphal, O., Lüderitz, O., GORZYNSKi, E. A. AND Eichenberger, E. (1956): Studies on enterobacterial lipopolysaccharides. Effect of heat and chemicals on erythrocyte-modifying, antigenic, toxic and pyrogenic properties. J. Immunol. 76, 377-385.

STERZL, J. AND RIHA, I. (1965): Detection of cells producing 7S antibodies by the plaque technique. Nature, 208, 858-859.

Ushiba, D., Kitasato, B., Saito, K., NAKano, M. AND NomURA, T. (1962): Selective inbreeding of mouse strains uniformly susceptible to mouse typhoid and experimental infections of those strains. I. Trial of establishing inbred strains with different timeto-death after infection with Salmonella enteritidis. Japan. J. Expt1. Med. 32, 505-517.

WESTPHAL, O. AND LÜDERITZ, O. (1954): Chemische Erforschung von Lipopolysacchariden Gramnegativer Bakterien. Angew. Chem. 66, 407-417.

Westphal, O., LÜDERITZ, O. AND BISTER, F. (1952): Uber die Extraktion von Bacterien mit Phenol/Wasser. Z. Naturforsch. $7 b, 148-155$. 


\title{
HEMORRHAGIC NECROSIS IN MOUSE BONE MARROW INDUCED BY ENDOTOXIN AND ITS RELATION TO THE HYPOFERREMIC REACTION
}

\author{
Michimasa HIRATA, MAsao YOSHIDA and Katsuya INADA \\ Department of Bacteriology, School of Medicine, Iwate Medical \\ University, Morioka, Japan
}

\section{SUMMARY}

An improved bone marrow reaction has been proposed as one of the bioassay methods. We called this method the new method. The new method was more sensitive and by this method more subjective designation could be performed. The positive bone marrow reactions were produced by endotoxin of S. typhimurium TV $160(\mathrm{Rb})$ as well as R-endotoxin of E. coli 09: K39.

The hypoferremic reaction proposed by Kampschmidt and Baker was carried out and compared with the bone marrow reaction. The hypoferremic reaction was found to be dependent on the doses of injected endotoxin if the administration was made at a dose more than $0.3-0.6 \mu \mathrm{g}$ of endotoxin.

The disadvantages of the hypoferremic reaction were that a wide variance of iron levels in the control mice as well as in the experimental mice was observed and that more numbers of mice were required as compared with the bone marrow reaction.

\section{INTRODUCTION}

We discovered that the bone marrow was most vulnerable to hemorrhagic necrosis induced by endotoxin injection (Yoshida et al., 1968). We then developed a method by which hemorrhagic necrosis could easily be observed. The method has been proposed by us one of the bioassay methods of endotoxin. A further improvement of this method was made and it was reported as the new method by which more subjective designation could be performed (Yoshida et al., 1970).

In the present study, an endotoxin of R-strain of S. typhimurium, the structure of which had been genetically and chemically determined, was used. A comparison between the bone marrow reaction and hypoferremic reaction produced by endotoxin injection will also be reported.

\section{MATERIALS AND MethodS}

Preparations of endotoxin: The endotoxins of S. typhimurium LT2 (S-type) and TV $160(\mathrm{Rb})$ (these strains were supplied through the courtesy of Prof. J. Y. Homma) were prepared by the procedures as follows: the aqueous phase obtained by the phenol water method (Westphal et al., 1952; Luderitz et al., 1965) was dialysed, concentrated and then purified by the repeated ultracentrifugation at 
$140,000 \times g$ according to Kauffmann et al. (1960). All preparations were suspended in pyrogen-free saline, sonicated at $10 \mathrm{KC}$ for $5-10 \mathrm{sec}$ and then sterilized at $80 \mathrm{C}$ for $10 \mathrm{~min}$.

Quantitative determination of serum iron: The iron contents of the pooled sera obtained from five mice per experimental group were quantitatively determined by the modified colorimetric method of Ichida (Ichida et al., 1968) using a Fereagents kit (EIKEN company, Japan).

Details as to the materials and methods were already reported (Yoshida et al., 1968).

\section{RESULTS}

(1) Comparisons between the old and the new methods and the intraperitoneal and the intravenous injections:

The new method was designated not only more subjective, but also more sensitive than the old method. The dose dependency in the new method was also higher than in the old method.

In the old method, the $\mathrm{ED}_{50}$ of endotoxin of E. coli 09:K39 injected intraperitoneally was $4.1 \mu \mathrm{g}$ as already reported (Yoshida et al., 1968).

In the new method, $\mathrm{ED}_{50}$ of the same endotoxin was $1.1 \mu \mathrm{g}$ by intraperitoneal injection and $0.38 \mu \mathrm{g}$ by intravenous injection.

(2) Bone marrow reaction with $R$ type endotoxin:

The bone marrow reaction with an $\mathrm{R}$ type endotoxin of $E$. coli 09 : K39 which has not yet been examined on the genetic situation was already reported (Yoshida et al., 1969). The $\mathrm{ED}_{50}$ of this $\mathrm{R}$ endotoxin was calculated to be $3.9 \mu \mathrm{g}$ whereas the $\mathrm{ED}_{50}$ of the $\mathrm{S}$ endotoxin of its wild strain $4.1 \mu \mathrm{g}$ by the old method and i. p. injection.

The $\mathrm{ED}_{50}$ of the $\mathrm{R}$ endotoxin of $S$. typhimurium TV 160 (Nikaido et al., 1964) was found to be $4.5 \mu \mathrm{g}$ and the $\mathrm{ED}_{50}$ of the $\mathrm{S}$ endotoxin of its wild strain $1.2 \mu \mathrm{g}$ by the new method and i. p. injection (Table 1 ).

Table 1. Bone Marrow Reaction by Endotoxins of S type and $\mathrm{R}$ type of $S$. typhimurium

\begin{tabular}{|c|c|c|c|c|c|}
\hline & \multicolumn{2}{|c|}{$\begin{array}{l}\text { LT2-LPS (S) } \\
\text { i. p. }\end{array}$} & & \multicolumn{2}{|c|}{$\begin{array}{c}\text { TV 160-LPS (R) } \\
\text { i. p. }\end{array}$} \\
\hline & $\begin{array}{l}\text { positive } \\
\text { mice }\end{array}$ & score/mouse & & $\begin{array}{l}\text { positive } \\
\text { mice }\end{array}$ & score/mouse \\
\hline $10 \mu \mathrm{g}$ & $5 / 5$ & $2.0 *(0) * *$ & $10 \mu \mathrm{g}$ & $4 / 5$ & $1.3 *(0.37) * *$ \\
\hline 5 & $4 / 5$ & $1.7(0.30)$ & 5 & $3 / 5$ & $0.9(0.10)$ \\
\hline 2.5 & $4 / 5$ & $1.2(0.34)$ & 2.5 & $1 / 5$ & $0.4(0.40)$ \\
\hline 1.3 & $3 / 5$ & $1.2(0.41)$ & 1.3 & $0 / 5$ & $0.1(0.10)$ \\
\hline 0.6 & $1 / 5$ & $0.5(0.32)$ & 0.6 & $0 / 5$ & $0 \quad(0)$ \\
\hline 0.3 & $0 / 5$ & $0.2(0.12)$ & & & \\
\hline $\begin{array}{l}\text { saline } \\
\text { (control) }\end{array}$ & $0 / 5$ & $0 \quad(0)$ & $\begin{array}{l}\text { saline } \\
\text { (control) }\end{array}$ & $0 / 5$ & $(0)$ \\
\hline
\end{tabular}


(3) The time course of hypoferremic reaction:

Kampschmidt and Upchurch (1962) and Baker and Wilson (1965) reported that the decrease of the plasma or serum iron level was found following endotoxin injection in rats or mice. We have observed this reaction in mice. An i. p. injection of $10 \mu \mathrm{g}$ of $S$. typhimurium LT 2 endotoxin was made and the serum iron levels were examined $1,6,12,18,24$ and $48 \mathrm{hr}$ after the injection, respectively. The maximum reduction of the serum iron level was found $12 \mathrm{hr}$ after the administration as reported by Baker and Wilson (1965).

\section{(4) The dose dependency of hypoferremic reaction:}

Two-fold serial dilutions of the endotoxin of 09: K39 were made; each dilution was injected intraperitoneally or intravenously to five mice per one group and the serum iron levels of the pooled sera from each five mice were measured.

A significant relationship was obtained between the serum iron levels and the dose of $E$. coli 09 : K39 endotoxin within a range of 0.6 to $2.5 \mu \mathrm{g}$ of endotoxin injected intraperitoneally and 0.3 to $2.5 \mu \mathrm{g}$ injected intravenousy. No dose dependency was found at doses lower than those described above. It also appeared that the reduction rates of serum iron levels in the i. v. injection were higher than those in the i. p. injection. Even when the same doses were administrated into a different group of mice on different experimental days, the differences of the reduction rates were found to vary as wide as from 20 to $25 \%$.

Similar investigations were performed using the endotoxin of S. typhimurium LT 2 and TV 160 as shown in Fig. 1. In these cases, linear dose-response curves were obtained within a range of 0.3 to $10 \mu \mathrm{g}$ and 0.6 to $10 \mu \mathrm{g}$, respectively.

(5) The serum iron levels of the control mice:

Baker and Wilson (1965) reported that, in the hypoferremic reaction, the

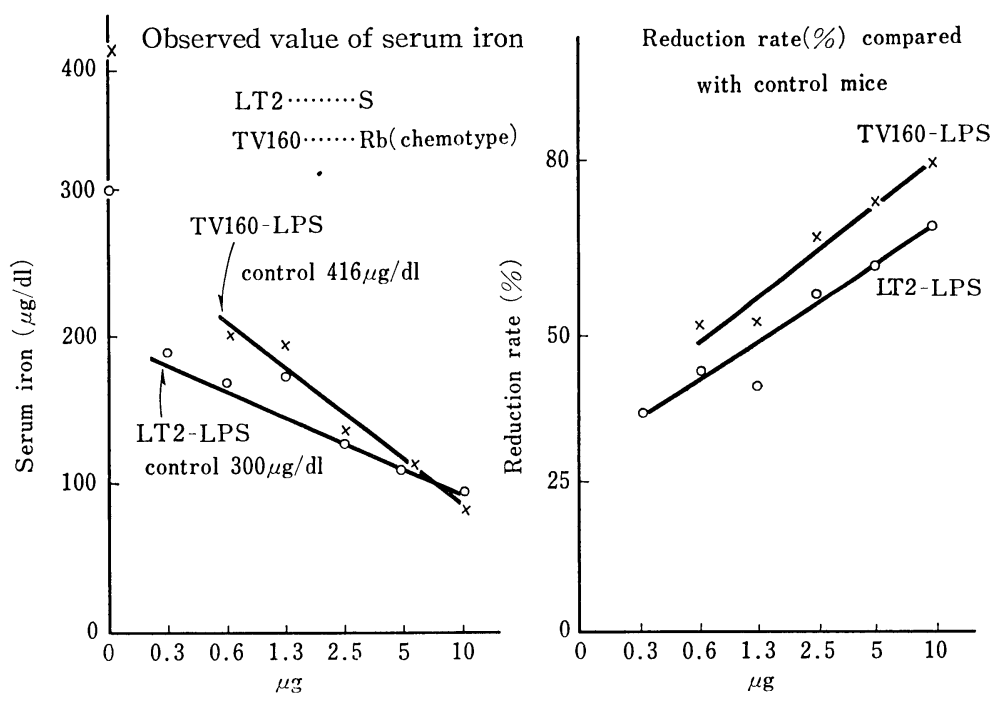

Fig. 1. Hypoferremic Reaction by Endotoxins of S Type and R Type of $S$. thyphimurium. 
reduction rates should be calculated by comparing with the iron levels of the control mice in each experiment. The levels of the controls obtained in our experiments were, however, observed to vary from $300 \mu \mathrm{g} / \mathrm{dl}$ to $472 \mu \mathrm{g} / \mathrm{dl}$.

Such findings were obtained in the experiment performed at the same time using mice under the same condition. When 50 mice were used and 10 levels were obtained, the levels were found to vary from $384 \mu \mathrm{g} / \mathrm{dl}$ to $472 \mu \mathrm{g} / \mathrm{d}$ l.

\section{DISCUSSION}

It would be preferable in general that the experimental animals without pretreatments such as tumor implantation or administration of ACTH are used for investigation of the responses of the animals.

In our bone marrow reaction, the intact animals without the pretreatment were used. When the new method was carried out, the sensitivity was found to be higher than that by the old method. The $\mathrm{ED}_{50}$ 's were found to be 0.4 and $4.5 \mu \mathrm{g}$ by i. v. and i. p. injections, respectively.

These doses would be considered as convenient doses for common experiment on endotoxin.

On comparison between the bone marrow reaction and the hypoferremic reaction, it was an important matter that the figures of the control did not vary upto the positive degree in the bone marrow reaction but in the hypoferremic reaction they varied so widely that it was difficult to standardize.

Baker and Wilson (1965) reported that three or five groups of mice should be used as a control group and the mean of these groups should be used as the criterion for the reduction.

In our experiment, in which ten groups under the same condition were used, the means of three groups at optional choice were found to vary from $397 \mu \mathrm{g} / \mathrm{dl}$ to $465 \mu \mathrm{g} / \mathrm{dl}$. These wide variances in the means of the control group were also reported by Baker. The disadvantage in the hypoferremia would be the wide variance of the iron levels in the control mice.

The dose of endotoxin which can be employed for a common experiment was found not to be as low as $0.01 \mu \mathrm{g}$ as reported by Baker as a minimum effective dose, but to be more than $0.3-0.6 \mu \mathrm{g} / \mathrm{mouse}$.

It was found that convenient doses employed in the experiment were similar to those injected intravenously in the bone marrow reaction of the new method.

\section{ACKNOWLEDGEMENTS}

We are deeply indepted to Professor J. Y. Homma, Department of Bacteriology, the Institute of Medical Science, the University of Tokyo, to Dr. M. Ota, Department of Biochemistry, School of Medicine, Iwate Medical University, for their valuable advice and suggestions. We are also grateful to Prof. R. Kawana, Iwate Medical University, for his encouragement.

\section{REFERENCES}

BAKER, P. J. AND Wilson, J. B. (1965): Hypoferremia in mice and its application to the bioassay of endotoxin. J. Bacteriol., 9o (4), 903-910.

ICHIDA, T., OSAKA, T. AND KOJIMA, K. (1968): A simple method for the determination 
of serum iron. Clin. Chim. Acta, 22, 271-275.

KAufFmanN, F., LÜDERITZ, O., STIERLin, H. AND WestPhal, O. (1960): Zur Immunchemie der O-Antigene von Enterobacteriaceae. I. Analyse der Zuckerbaustein von Salmonella-OAntigenen. Zentr. Bakteriol. Parasitenk., 178, 442-458.

Lüderitz, O., Risse, H. J., Schulte-Holthausen, H., Strominger, J. L., Sutherland, I. W. AND WestPhaL, O. (1965): Biochemical studies of the Smooth-Rough mutation in Salmonella minnesota. J. Bacteriol., 89, 343-354.

Nikaido, H., Nikaido, K., Subbaiah, T. V. and Stocker, B. A. D. (1964): Rough mutants of Salmonella typhimurium. 3. Enzymatic synthesis of nucleotide-sugar compounds. Nature., 201, 1301-1302.

Westphal, O., LüDERITZ, O. AND BISTER, F. (1952): Uber die Extraktion von Bakterien mit Phenol/Wasser. Z. Naturforsch., $7 b, 148-155$.

Yoshida, M., Hirata, M., InAda, K. ANd Hatano, Y. (1968): Hemorrhagic necrosis in mouse bone marrow induced by a single injection of endotoxin, and its application to the bioassay of endotoxin and to the study on biological activity of $\mathrm{K}$-antigen. Japan. J. Expt1. Med., 38, 335-346.

Yoshida, M., Hirata, M., Hatano, Y. ANd Inada, K. (1969): The 16 th Annual Meeting of Symposium on Toxins. p. 14-1 (in Japanese).

Yoshida, M., Hirata, M., Inada, K., Hatano, Y. And Kawano, R. (1970): Japan. J. Bact. (in press, in Japanese)

\title{
STUDIES ON ANTITUMOR ACTIVITY OF BACTERIAL LIPOPOLYSACCHARIDE
}

\author{
IWAO UMEZAWA AND TOJU HATA
}

The Kitasato Institute, Minato-ku, Tokyo

Since the use of Coley's toxin for the treatment of sarcoma (Coley, 1893), polysaccharide extracted from microorganisms or bacterial cells has been examined as a chemotherapeutic for cancer, (Shear and Turner, 1943). Its practical use, however, has not become common due to the lability of its therapeutic effect and side action such as pyrogenesis and others.

On the other hand, it has been reported that the tumor disappears in stomach cancer patients or the proliferation of tumor is inhibited temporarily or over a long period, when they become secondarily infected with pyogenic bacteria, that tumor was diminished by the use of a bacterial component (Preus and Shear, 1944), and that injection of live bacteria, especially spore-bearing bacteria (Clostridium and others), results in accumulation of the bacteria in tumor tissue and finally in oncolysis (Boxer et al., 1963).

Several pus materials from the suppurative wound after operation of stomach cancer patients were received from the Department of Surgery, Keio University, School of Medicine, in 1965 and four kinds of microorganisms were isolated from them in our laboratory; Escherichia coli, Pseudomonas aeruginosa, Staphylococcus aureus, and Streptococcus haemolyticus. Each pathogenic bacteria was shake cultured for 2 days at $28-30 \mathrm{C}$. The effect of the culture filtrate of these 
four kinds of microorganisms on transplanted tumor of mice was tested and it was found that the culture filtrate and cells of these organisms had antitumor activity against subcutaneous tumor or sarcoma-180. Then, a polysaccharide was extracted from each of the organisms and its antitumor activity was compared with one another. All the bacterial extracts showed some degree of antitumor effect, and the extract of Staphylococcus aureus had the least toxicity and side effect.

Therefore, polysaccharide was extracted chiefly from Staph. aureus by the Westphal method (Westphal and Lüdetz, 1954), and Boivin method (Boivin et al., 1933), and its antitumor activity and other biological properties were examined.

The elemental analytical values of the samples extracted from the wet bacterial cells of Staph. aureus by the above two methods showed that the values of carbon and hydrogen were approximately the same in both cases but the value of nitrogen in the extract by the Westphal method was almost twice that of the extract obtained by the Boivin method. Phosphorus content was also larger in the extract obtained by the Westphal method. In the ultraviolet spectra, both showed peak absorption over the range of $260-280 \mathrm{~m} \mu$, but the absorbance of the Westphal extract was about 7 times greater than that of the Boivin extract.

In the color reaction, both extracts were positive to the Molisch and ninhydrin reactions, doubtfully positive to the Tollens reaction, and negative to the biuret and Benedict reactions. Consequently, this substance is considered to be a high-molecular substance. Acute toxicity, $\mathrm{LD}_{50}$, of both extracts, was over $500 \mathrm{mg} / \mathrm{kg}$ by intravenous injection in mice and over $1000 \mathrm{mg} / \mathrm{kg}$ by subcutaneous injection.

1) Antitumor Activity

a) The culture filtrate of four kinds of isolated microorganisms was repeatedly given by subcutaneous injection to tumor-bearing mice transplanted with subcutaneous tumor of sarcoma-180 and some regression of the tumor was observed. In order to examine whether this antitumor activity was in the culture filtrate or in the cells, three samples were prepared; (A) culture filtrate heated at $60 \mathrm{C}$ for $30 \mathrm{~min}$, (B) supernatant obtained by centrifugation of the culture filtrate at $5,000 \mathrm{rpm}$ for $15 \mathrm{~min}$, and $(\mathrm{C})$ sediment of the above centrifugation. Each of these samples was injected subcutaneously into the back of mice $24 \mathrm{hr}$ after implantation of the subcutaneous tumor of sarcoma-180, once a day for 14 consecutive days, and proliferation or regression of the tumor was examined. In the case of E. coli, Staph. aureus, and Strept. haemolyticus, the dose administered was $0.2,0.025$, or $0.012 \mathrm{ml} / \mathrm{mouse} /$ day of A and B samples, and 200,25 , or 5 $\mathrm{mg} / \mathrm{mouse} /$ day for sample C. Since the toxicity of Pseud. aeruginosa was rather strong, the dose was $0.025,0.012$, or $0.006 \mathrm{ml} / \mathrm{mouse} /$ day for $\mathrm{A}$ and $\mathrm{B}$ samples, and 25,5 , or $2.5 \mu \mathrm{g} / \mathrm{mouse} /$ day for sample $\mathrm{C}$.

In any of these samples, complete disappearance of tumor was observed in $10-40 \%$ of the animals in the treated group and their survival was prolonged. In the case of $E$. coli, the best effect was observed in the group given $25 \mu \mathrm{g}$ of sample C and $40 \%$ of the animals were cured.

With the culture filtrate from Staph. aureus, disappearance of tumor in 30\% of the animals was observed in the group given $0.025 \mathrm{ml} /$ mouse of sample A and 
$40 \%$ cure rate was observed in the group given $0.025 \mathrm{ml}$ of sample B and 200 and $25 \mu \mathrm{g}$ of sample C.

With the culture filtrate of Strept. haemolyticus, disappearance of tumor was seen in $10-20 \%$ mice given samples $\mathrm{A}$ and $\mathrm{B}$, and $30 \%$ of the animals were cured with 25 and $5 \mu \mathrm{g} /$ mouse of sample C.

In the case of culture filtrate of Pseud. aeruginosa, 20-30\% of the mice were cured when given 0.025 or $0.012 \mathrm{ml} /$ mouse of sample A, but its antitumor activity was lower than that from other three microorganisms and its toxicity was also strong.

Comparison of the antitumor activity of these three kinds of samples showed that the strongest activity was present in the cells in all. Therefore, effective principle was extracted from the cultured cells of Staph. aureus, which showed the highest antitumor effect, and its antitumor effect was compared with the substance extracted by the same method from the cells of E. coli.

b) Effect of Bacterial Extract on Subcutaneous Tumor

The components extracted from the cultured wet cells of Staph. aureus by the Westphal and Boivin methods were given to mice by subcutaneous injection once a day for 3,7 , or 14 days consecutively, and growth of the tumor was examined.

From the period required for cmoplete regression of the tumor, both extracts seemed to be more effective by a 7-day administration than 3-day administration, and a much better result was obtained by administration for 14 days. From the dose administered, maximum of $40 \%$ cure rate was obtained by 14-day administration of $0.62 \mathrm{mg}$ of Boivin extract and $2.5 / \mathrm{kg} /$ day of Westphal extract.

From their effect on the disappearance of solid tumors, there seems to be no great difference between the substances obtained from Staph. aureus and $E$. coli by the two methods and a maximum of $40 \%$ cure rate was obtained as

Table 1. Effect of Bacterial Extract on S-180 in Mice

\begin{tabular}{|c|c|c|c|c|c|c|}
\hline \multirow{2}{*}{$\begin{array}{l}\text { Sample } \\
\text { extracted } \\
\text { by }\end{array}$} & \multicolumn{3}{|c|}{ Staphylococcus aureus } & \multicolumn{3}{|c|}{ E. coli } \\
\hline & $\begin{array}{l}\text { Dose } \\
\text { daily } \times 14 \\
(\mathrm{mg} / \mathrm{kg} \mathrm{SC})\end{array}$ & $\begin{array}{l}\text { No. mice } \\
\text { cured/No. } \\
\text { mice treated }\end{array}$ & $\begin{array}{l}\stackrel{\%}{\%} \\
\text { Complete } \\
\text { regression }\end{array}$ & $\begin{array}{l}\text { Dose } \\
\text { daily } \times 14 \\
(\mathrm{mg} / \mathrm{kg} \mathrm{SC})\end{array}$ & $\begin{array}{l}\text { No. mice } \\
\text { cured/No. } \\
\text { mice treated }\end{array}$ & $\begin{array}{l}\stackrel{\%}{\%} \\
\text { Complete } \\
\text { regression }\end{array}$ \\
\hline & 10 & $2 / 10$ & 20 & 10 & $1 / 10$ & 10 \\
\hline Boivin's & 5 & $3 / 10$ & 30 & 5 & $0 / 10$ & 0 \\
\hline \multirow[t]{4}{*}{ Method } & 2.5 & $3 / 10$ & 30 & 2.5 & $1 / 10$ & 10 \\
\hline & 1.25 & $1 / 10$ & 10 & 1.0 & $1 / 10$ & 10 \\
\hline & 0.62 & $4 / 10$ & $40^{*}$ & 0.5 & $4 / 10$ & $40^{*}$ \\
\hline & 10 & $1 / 10$ & 10 & 10 & $0 / 10$ & 0 \\
\hline Westphal's & 5 & $3 / 10$ & 30 & 5 & $4 / 10$ & $40 * *$ \\
\hline \multirow[t]{3}{*}{ Method } & 2.5 & $4 / 10$ & $40^{*}$ & 2.5 & $4 / 15$ & $27 * *$ \\
\hline & 1.25 & $2 / 10$ & 20 & 1.0 & $6 / 15$ & $40 * *$ \\
\hline & 0.62 & $3 / 10$ & 30 & 0.5 & $4 / 15$ & 27 \\
\hline \multicolumn{2}{|c|}{ Control Saline } & $0 / 10$ & 0 & Saline & $0 / 15$ & 0 \\
\hline
\end{tabular}

* at $5 \%$ level

** at $1 \%$ level 
shown in Table 1. There was not always a correlation between the dose administered and antitumor effect, and dose-response relation was not clear at any of the dose levels.

c) Effect of Bacterial Extract on Ascites Tumor

Ehrlich ascites tumor was intraperitoneally inoculated in mice in an amount of $10^{7}$ cells/mouse and bacterial component of Staph. aureus was injected intraperitoneally after $48 \mathrm{hr}$, once a day for 14 consecutive days to examine its effect on ascites tumor cells, but there was no cell degeneration or life prolongation effect. No change in the HeLa cells occurred even in a concentration of $1 \mathrm{mg} / \mathrm{ml}$.

2) Side Effect of Bacterial Extract from Staph. aureus

a) Pyrogenic Experiment

Rabbits were given the bacterial extracts by intravenous and subcutaneous injection and their body temperature was measured. In general, the rise of body temperature due to subcutaneous injection of bacterial extracts was higher than intravenous injection of it. A single administration of $10,5,1$ or $0.5 \mathrm{mg} / \mathrm{kg}$ of the Westphal extract showed a transitory rise in body temperature over $1 \mathrm{C}$ at 2 to $4 \mathrm{hr}$ after injection, but the temperature returned to normal $6 \mathrm{hr}$ after the administration. Repeated administration of these doses resulted in transitory rise of body temperature over $0.5 \mathrm{C}$. However, in the case of Boivin extract, administration of $10 \mathrm{mg} / \mathrm{kg}$ resulted in rise of body temperature by $0.7-0.9 \mathrm{C}$, and the rise was less than $0.5 \mathrm{C}$ by a single administration or repeated administrations of $5 \mathrm{mg} / \mathrm{kg}$. This shows that the pyrogenic effect of the bacterial component from Staph. aureus in the rabbit is smaller in the Boivin extract than in the Westphal one.

b) Effect of this substance on rabbit leucocytes was examined and it was found that no remarkable change occurred by either a single or repeated administrations, though a transitory increase in leucocytes up to 14,000 was observed in the Westphal extract but not in Boivin extract.

c) Effect of these substances on the reticuloendothelial system was tested by the Congo Red method and found a slight increase in the system by the Westphal extract in a small amount $(0.5 \mathrm{mg} / \mathrm{kg})$, while the function rather decreased in its larger dose. In contrast, the Boivin extract decreased this function in a small amount $(0.5-1 \mathrm{mg} / \mathrm{kg})$, while the function tended to be accelerated by an increased amount or by repeated injections.

\section{CONCLUSION}

The bacterial component originating from Staph. aureus did show a moderate antitumor activity against sarcoma-180 subcutaneous tumor, though there was no dose-response relation. There was no direct cytotoxic effect on Ehrlich ascites tumor or HeLa cells, indicating that this bacterial component is not the so called cytotoxic agent.

As for the side effect of Boivin extract of Staph. aureus, the rise of body temperature was less than $0.5 \mathrm{C}$ by a single and repeated subcutaneous administrations. Although the effect of these substances on the reticuloendothelial system does not come to conclusion yet, a slight increase in the activity was 
observed by both a single and repeated administrations of the Bovin extract.

Further studies will be made on the antitumor effect and side actions of these substances with further purified samples in near future.

\title{
REFERENCES
}

COLEY, W. B. (1893): The treatment of malignant tumor by repeated inoculation of erypipelas with a report of original cases. Am. J. Med. Soc., 105, 487-511.

SHEAR, M. J. AND TURNER, F. C. (1943): Chemical treatment of tumor. V. Isolation of the hemorrhage-producing fraction from Serratia marcescens (Bacillus prodigiosus) culture filtrate. J. Nat. Cancer Inst., 4, 81-77.

PREUS, A. M. AND SHEAR, M. J. (1944): Chemical treatment of tumor. Reactions of four patients with advanced malignant tumorto injection of polysaccharide from Serratia marcescens culture filtrate. J. Nat. Cancer Inst., 5, 195-208.

Boxer, G. E., et al. (1963): Oncholyse durch Clostridien: IIIrd International Congress of Chemotherapy (2), 1774-1778.

WESTPHAL, O. AND LÜDERITZ, O. (1954): Chemische Erforschung von Lipopolysacchariden gramnegativer Bakterien. Angew. Chem., 66, 407-417.

Borvin, P. A. et al. (1933): Technique pour la préparation des polysaccharides Micobiens. Compt. Rend. Soc. Biol., 113, 490-492.

\section{CHARACTERISTICS OF CIR (CELL INJURING REACTION) ACTIVE SUBSTANCE IN CULTURE FLUID OF BACILLUS CEREUS, “MS-1063 STRAIN"}

\author{
Junji TANAKA, Ryusaku SHIMIZU and Motoichi HATANO \\ Department of Virology, Cancer Research Institute, Kanazawa University, \\ Kanazawa, Japan
}

Our previous reports described that we established unique method which can measure quantitatively in vitro the animal cell injury caused by exogeneous agents and is applicable to various cancer or non-cancer cells cultured in vitro (Shimizu et al., 1967; Hatano, 1967; Hatano et al., 1967). Some bacteria or their products were shown to possess selective cancer cell injuring activities by this method named CIR (Cell Injuring Reaction) assay (Hatano et al., 1967; Yabuki, 1968; Nogaki, 1969). This CIR assay was based on the measurement of optical density at $260 \mathrm{~m} \mu$ for ultraviolet-absorbing substances released into the cell-reaction supernatant from cells injured by those bacteria or their products. For usual CIR assay, Ehrlich ascites cancer cells prepared under the optimal conditions were used as a standard cell. Here, some characteristics of CIR active substance from $B$. cereus, "MS-1063 strain", which showed the most potent activity in CIR positive bacteria isolated by us, will be described.

1) Isolation and purification of CIR substance

As reported in our previous paper (Tanaka, Shimizu and Hatano, 1969), CIR substance in culture fluid of MS-1063 strain was partially purified through the combination of absorption to sodium benzoate and fractionation by ammonium 
sulfate, etc. However, contaminated hemolysin (cereolysin described by Bernheimer and Grushoff (1967)) was not eliminated completely.

By using hyflo super cel as an aid of filtration of the ammonium sulfate precipitate, crude CIR activity and its yield from the starting culture fluid was roughly doubled those of our previous sample. Namely, culture fluid was dialyzed and lyophilized $(\mathrm{CF})$. The rehydrated material was precipitated with ammonium sulfate (100\% saturation) and filtered with hyflo super cel. The active substance retained on hyflo super cel was dissolved in distilled water and lyophilized after dialysis (CFA). CFA dissolved in distilled water $(10 \mathrm{mg} / \mathrm{ml})$ was precipitated again with ammonium sulfate (50\% saturation). The precipitate was lyophilized after dialysis (CFAA). Recoveries of CFA and CFAA from 1 litter of culture fluid were $375 \mathrm{mg}$ and $125 \mathrm{mg}$ and $64 \%$ and $52 \%$ in CIR activities, respectively.

This CFAA still contained hemolysin (HA) as our previous materials did. For the separation of the CIR active substance from HA in CFAA, we used gelfiltration on Bio-Gel-P 150. In this step, these activities were eluted in different tubes as main peaks (CFAA-P 150 as CIR substance), while a slight contamination with other substances was inevitable. As one of another attempt for separation, CFA was treated with CM-cellulose by a batch method (CFACM). This CFACM was'submitted to DEAE-chromatography and subsequently eluted by stepweise concentration of $\mathrm{NaCl}$. Three fractions, Fr I, Fr II and Fr III, in the order of elution were obtained in different tubes as sharp peaks by OD 280 $\mathrm{m} \mu$ measurement, Fr II and Fr III were proved to contain mainly CIR substance and $\mathrm{HA}$, respectively, though the first fraction (Fr I) was shown to be very low in both activities. However, even in Fr II and Fr III, a slight cross contamination with respective substances was observed, just as the result of gel-filtration on Bio-gel-P 150. CIR and HA activities of each sample from CF to the final product after gel-filtration or DEAE-chromatography are shown in Table 1.

2) Problems of identity of CIR substance to other known factors possessed by

B. cereus

Johnson and Bonventre (1967) already reported the isolation of three substances (lethal toxin, hemolysin and phospholipase C) from culture fluid of $B$. cereus after fractionation with ammonium sulfate and gel-filtration on Sephadex G-75. Our final product, CFAA-P 150 or Fr III, which showed high CIR and low HA activities, was supposed to be phospholipase C (PLC) or its contaminant. This was estimated from the same position of eluting the highest CIR activity, as Johnson's results of gel-filtration. The possibility was examined by two methods.

At first, each sample shown in Table 1 was tested in the lecitho-vitellin reactivity using egg yolk plates (Kushner, 1956) at three different concentrations. However, the size of reaction zone caused by these samples and by lecithinase C from Cl. welchii type 1 (Sigma, Co., U. S. A.) as a control did not correlate with their CIR activities. This seemed to indicate that the samples contained various amounts of PLC; those activities were not completely comparable to CIR activities. Next confirmation of this problem was furnished by measuring the PLC activity by the MacFarlene and Knight's method (1941) with egg yolk lecithin as a substrate. The results are shown also in Table 1.

Another experiment comparing heat inactivation at $45 \mathrm{C}$ of $\mathrm{Fr}$. II and CFACM showed different inactivation of PLC, CIR, HA and lethal toxic activities. 
Table 1. Relationships of CIR, HA and Phospholipase $\mathrm{C}$ activities in the products of MS-1063 strain

\begin{tabular}{lccc}
\hline Sample & CIR (u/mg) & HA (u/mg) & Phospholipase C (u/mg) \\
\hline CF & 8.5 & 27.2 & $/$ \\
CFA & 46.5 & 65.0 & $/$ \\
CFAA & 135.0 & 516.0 & $/$ \\
CFAA-P150 & 220.0 & 7.5 & 2.3 \\
& 170.0 & 15.5 & 4.4 \\
CFACM & 125.0 & 60.5 & 6.4 \\
CFACM-DEAE (Fr. 2) & 90.0 & 256.0 & 7.5 \\
CFACM-DEAE (Fr. 3) & 161.5 & 16.6 & 10.1 \\
\hline Lecithinase C & 39.5 & 34.7 & \\
(Cl. welchii) & 39.5 &
\end{tabular}

CIR: 1 CIR unit $=$ minimum concentration required to show $50 \% \mathrm{CIR}$ values in Ehrlich ascites cell

$\mathrm{HA}: 1 \mathrm{HA}$ unit=minimum concentration required to show $50 \%$ hemolysis of human red cell (type 0 )

Phospholipase C: 1 unit=the amount of enzyme required to liberate $100 \mu \mathrm{g}$ of acid-soluble phosphorus from an egg-yolk lecithin substrate in $15 \mathrm{~min}$. at $37 \mathrm{C}$

HA and lethal toxin (LT) were inactivated most rapidly, inactivation of CIR was only partial and PLC was not affected even after treated for $90 \mathrm{~min}$. Similar results were obtained in trypsin digestion experiments of CFACM. The results observed in these lecitho-vitellin reaction, determination of PLC activities (Table 1) and heat-and trypsin-inactivation led us to the following conclusion. Tha materials obtained here seemed to contain four components (CIR, HA, PLC and LT) at various concentrations. Further experiments are needed to answer the question whether all these four activities are expressed by one protein remain.

3) Biological characteristics of CIR substance

In our previous paper, we had already shown the selective cancer cell injury by another partially purified CIR substance obtained from MS-1063 strain (Tanaka, Shimizu and Hatano, 1969). Here, our present final product, CFAA-P 150, showing high CIR and low HA or PLC activities as show in Table 1, was determined for its selective cancer cell injury as show in Fig. 1.

THEL and PPH cells are cancer cells spontaneously transformed in vitro from normal human embryonic lung cell (PHEL) (Yabuki, 1968; Watanabe, 1970). THEL showed oncogenicity of about 100 times stronger than $\mathrm{PPH}$ in its latent period and the minimum number of cells required to form tumor in hamsters. Both these two cancer cells were observed to be strongly injured, regardless of their oncogenicity, though normal cells (PHEL) showed clearly lower CIR values under the experimental conditions shown in Fig. 1.

Morphological observations in an electron-microscopic study of CIR suggested that the first action site of these CIR substances might be the cell surface membrane (Ueda, 1969). Therefore, the reaction of CFAA-P 150 with cell ghosts extracted from cancer cells (Ehrlich ascites cancer cell) and with the normal 


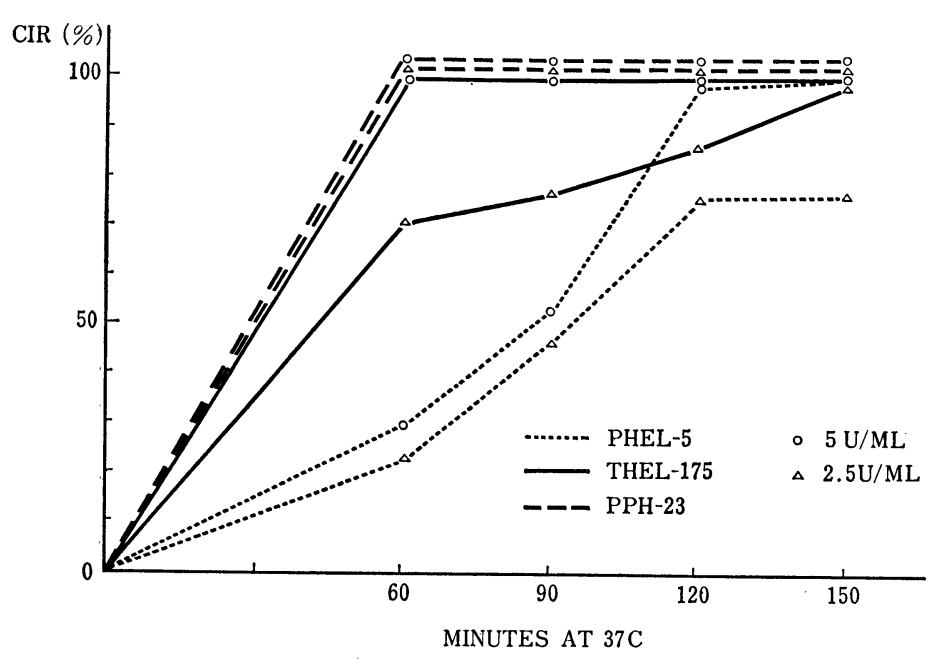

Fig. 1. Selective CIR activity of MS-1063 CFAA (P-150) fraction in cultured cell.

mice liver cells was tested by the agar cup method. These cell ghosts are known to be composed chiefly of insoluble lipoprotein originating from the cell plasma membrane (Smith and Thomas, 1957). 6.0, 1.0, 0.6 and $0.3 \mathrm{CIR}$ units $/ \mathrm{ml}$ of CFAA-P 150 were placed on agar plates containing the same concentration of lipoprotein from cancer and non-cancer cell ghosts. After being kept overnight at $37 \mathrm{C}$, lytic zones formed by each samples in relation to the concentration were larger in size on the cancer cell ghost plate than in the normal cell ghost plate. Thus, our CIR substance seemed to show cancer cell selective injury attacking the cell plasma membrane as a possible action site or its reaction substrate, just like a similar selective carcinolytic toxin found in cobra venom by Braganca et al. (1965, 1966).

Conclusion: CIR substance obtained from culture fluid of B. cereus, " MS-1063 strain" was characterized biologically and biochemically. The most important and interesting problems will be focussed to the analysis of the mechanisms of cancer cell selective injury by this CIR substance and to more closely relating this substance with known factors such as one observed already in culture fluid of B. cereus.

\section{REFERENCES}

BERNhEIMER, A. W. AND GRUSHOFF, P. (1967): Cereolysin; production, purification and partial characterization. J. Gen. Microbiol., 46, 143-150.

BragancA, B. M., BAdrinath, P. G. AND Ambrose, E. J. (1965): A highly selective carcinolytic agent isolated from cobra venom. Nature, 207, 534-535.

Braganca B. M., PATel, N. T. AND BAdRINATh, P. G. (1966): Isolation and properties of a cobra venom factor selectively cytotoxic to Yoshida sarcoma cell. Biochim. Biophys. Acta, 136, 508-520.

HATANO, M. (1967): Release of cellular RNA in cancer cell by living Streptococci and $\mathrm{HgCl}_{2}$. Igakuno Ayumi, 63, 261-268 (text in Japanese). 
Hatano, M., Shimizu, R., Morita, O. and Yamagishi, T. (1967): Attempt for specificity determination of cell injuring reaction (CIR) by bacteria. Medicine and Biology, 74, 293-298 (text in Japanese).

JOHNSON, C. E. AND BONVENTRE, P. F. (1967): Lethal toxin of Bacillus cereus. I. Relationships and nature of toxin, hemolysin, and phospholipase. J. Bacteriol., 94, 306-316.

KUSHNER, D. J. (1956): An evaluation of the egg-yolk reaction as a test for lecithinase activity. J. Bacteriol., 73, 297-302.

MACFARLENE, M. G. AND KNIGHT, B. C. J. G. (1941): The biochemistry of bacterial toxin. I. The lecithinase of $\mathrm{Cl}$. welchii toxins. Biochem. J., 35, 884-902.

NoGAKI, T. (1969): Separation and reactivity of cancer cell injuring substances from nonpathogenic bacteria, Bacillus brevis, "Y-30 strain". Juzen Igakukaishi, 78, 403-421 (text in Japanese).

Shimizu, R., Koshimura, S., Hatano, M., Morita, O., Ohono, S. and Ueda, H. (1967): The intracellular RNA-releasing response of cell to living streptococci standardized by non-specific, reproducible effect of $\mathrm{HgCl}_{2}$. Symposia Cell Chem., 18, 35-43. (text in Japanese).

Smith, J. T. AND 'Tномas, L. E. (1957): Cellular lipoproteins, I. The insoluble lipoprotein of whole liver cells. Exp. Cell Res., 13, 96-102.

TANAKA, J., ShimizU, R. AND HATANo, M. (1969): CIR (Cell Injuring : Reaction) active substance in culture fluid of Bacilluls cereus, "MS-1063 strain". Abstracts of 16th Symp. of Toxin, 1-6, (text in Japanese).

UEDA, H. (1969): Electron microscopic study on selective cell injuring reaction by extracts from non-pathogenic bacteria. Ann. Rep., Can. Res. Inst., Kanazawa Univ., 3, 67-86 (text in Japanese).

WATANABE, K. (1970): Cytotoxic activity of histone extracted from cancer and non-cancer cell on cultured mouse and human cell. Ann. Rep., Can. Res. Inst., Kanazawa Univ., 3, 163-189 (text in Japanese).

YABUKI, Y. (1968): Selective cell injuring activity of non-pathogenic bacteria and its extracts against cancer cells. Ann. Rep., Can. Res. Inst., Kanazawa Univ., 2, 113-130 (text in Japanese). 